\title{
Host cell type-dependent translocation and PhoP-mediated positive regulation of the effector SseK1 of Salmonella enterica
}

\author{
Fernando Baisón-OImo, María Galindo-Moreno and Francisco Ramos-Morales* \\ Departamento de Genética, Facultad de Biología, Universidad de Sevilla, Sevilla, Spain
}

OPEN ACCESS

Edited by:

Beiyan Nan,

University of California, Berkeley, USA

Reviewed by:

Zhao Chen

Clemson University, USA

Eleonora Garcia Vescovi,

Instituto de Biología Molecular

y Celular de Rosario, Argentina

${ }^{*}$ Correspondence:

Francisco Ramos-Morales,

Departamento de Genética, Facultad de Biología, Universidad de Sevilla,

Avenida Reina Mercedes 6,

41012 Sevilla, Spain

framos@us.es

Specialty section:

This article was submitted to

Food Microbiology,

a section of the journa

Frontiers in Microbiology

Received: 04 March 2015

Accepted: 16 April 2015

Published: 29 April 2015

Citation:

Baisón-Olmo F, Galindo-Moreno M and Ramos-Morales F (2015) Host

cell type-dependent translocation

and PhoP-mediated positive

regulation of the effector SseK1

of Salmonella enterica.

Front. Microbiol. 6:396.

doi: 10.3389/fmicb.2015.00396
Salmonella enterica expresses two virulence-related type III secretion systems (T3SSs) encoded in Salmonella pathogenicity island 1 (SPI1) and SPI2, respectively. SseK1 is a poorly characterized substrate of the SPI2-encoded T3SS. Here, we show that this effector is essential to get full virulence both in oral and intraperitoneal mice infections, in spite of not having a role in invasion or intracellular proliferation in cultured mammalian cells. In vitro, expression of sseK 1 was higher in media mimicking intracellular conditions, when SPI2 was induced, but it was also significant under SPI1 inducing conditions. A detailed analysis of translocation of SseK1 into host cells unveiled that it was a substrate of both, T3SS1 and T3SS2, although with different patterns and kinetics depending on the specific host cell type (epithelial, macrophages, or fibroblasts). The regulation of the expression of sseK 1 was examined using lac $Z$ and bioluminescent lux fusions. The two-component system $\mathrm{PhoQ} / \mathrm{PhoP}$ is a positive regulator of this gene. A combination of sequence analysis, directed mutagenesis and electrophoretic mobility shift assays showed that phosphorylated PhoP binds directly to the promoter region of sseK 1 and revealed a PhoP binding site located upstream of the predicted -35 hexamer of this promoter.

Keywords: Salmonella, SseK1, type III secretion, PhoQ/PhoP two-component system, epithelial cells, macrophages, fibroblasts, bioluminescence

\section{Introduction}

Salmonella enterica is a leading cause of bacterial foodborne infections worldwide that can induce from enterocolitis to systemic diseases, depending on the serovar-host combination (Chen and Jiang, 2014). The broad-host-range serovar Typhimurium causes gastroenteritis in humans, calves and other animals, but it causes a systemic typhoid fever-like disease in susceptible mouse strains (Tsolis et al., 1999; Uzzau et al., 2000). The virulence of these bacteria relies on the possession of specific genes. Many of them are horizontally transferred elements that are clustered in Salmonella pathogenicity islands (SPIs; Gyles and Boerlin, 2014). The biggest and best studied clusters are SPI1 and SPI2, which encode two type III secretion systems, T3SS1 and T3SS2, that are important for invasion of non-phagocytic cells and for intracellular survival and proliferation, respectively (Galán and Curtiss, 1989; Ochman et al., 1996; Shea et al., 1996). These are flagellum-like onestep transport systems that carry out translocation of proteins, known as effectors, across the two membranes of Gram-negative bacteria and the host cell membrane. 
More than 30 effectors are secreted through Salmonella T3SSs (Ramos-Morales, 2012; Habyarimana et al., 2014). Some of them are encoded in SPI1 or SPI2 but many are encoded outside the islands. The best characterized Salmonella invasion mechanism, the "trigger" mechanism, requires at least six T3SS1 effectors, SipA, SipC, SopB, SopE, SopE2, and SptP, that induce remodeling of actin cytoskeleton (Guiney and Lesnick, 2005). SipA, SopB, SopE, and SopE2 are also involved in the disruption of epithelial tight junctions (Boyle et al., 2006), whereas AvrA is a tight junction stabilizer (Liao et al., 2008). SopA, another T3SS1 effector, is involved in Salmonella-induced polymorphonuclear leukocytes transepithelial migration (Zhang et al., 2006). Other processes where T3SS1 is involved are the early and intermediate stages of the Salmonella-containing vacuole (SCV) biogenesis (Bakowski et al., 2008; Steele-Mortimer, 2008), and the induction of a rapid form of pyroptosis, a caspase-1 dependent form of programmed cell death, in macrophages (Fink and Cookson, 2007). T3SS2 is expressed intracellularly in response to the low $\mathrm{pH}$ and nutrient concentration found in the lumen of the SCV. This system translocates more than 20 effectors through the SCV membrane and is involved in several processes including intermediate and late stages of the SCV biogenesis, generation of tubular networks (Schroeder et al., 2011), apoptosis in epithelial cells, and delayed pyroptosis in macrophages (Fink and Cookson, 2007).

According to the different predominant functions related to T3SS1 and T3SS2, the conditions for optimal expression of SPI1 or SPI2 are reached at different moments of the infection. These conditions can be modeled in vitro using appropriate media: rich medium with low aeration and high $\mathrm{NaCl}$ concentration for SPI1, and minimal medium with low $\mathrm{pH}$ and low $\mathrm{Mg}^{2+}$ concentration for SPI2. Some effectors are specifically coexpressed with their cognate T3SS. There are, however, other effectors that are expressed under a broad range of conditions and can be secreted through both systems. This has been described for GtgE (Niemann et al., 2011), PipB2 (Baisón-Olmo et al., 2012), SlrP (Miao and Miller, 2000; Cordero-Alba and RamosMorales, 2014), SopD (Jones et al., 1998; Brumell et al., 2003), SpvC (Mazurkiewicz et al., 2008; Haneda et al., 2012), SpvD (Niemann et al., 2011), SspH1 (Miao et al., 1999), SteA (CardenalMuñoz and Ramos-Morales, 2011), and SteE (Niemann et al., 2011).

SseK1 was identified in S. enterica serovar Typhimurium as a T3SS substrate because of its similarity to known secreted proteins from enterohemorrhagic Escherichia coli and Citrobacter rodentium (Kujat Choy et al., 2004). Translocation of this protein into epithelial cells was shown to be T3SS2-dependent and after translocation SseK1 localized to the host cytosol. At least two paralogs exist in some $S$. enterica serovars or strains: SseK2 (Kujat Choy et al., 2004), which shares 61\% amino acid sequence identity with SseK1, and SseK3 (Brown et al., 2011), which is encoded in a prophage and is $75 \%$ identical to SseK2. Because of their striking similarity they are considered members of the same effector family and they are predicted to have redundant functions. However, the specific roles of these proteins in the host cells are unknown and there are conflicting reports about their relevance for intracellular replication of Salmonella and for virulence in mice. A study of the contribution of some T3SS2 effectors to replication in host cells reported that a triple mutant sseK1 sseK2 sseK3 had significantly reduced growth levels in RAW264.7 macrophages but showed no defect in bacterial counts in systemic organs of mice after oral infection (Buckner et al., 2011). In contrast, another study showed significant attenuation for this mutant in mice but did not detect intracellular growth defects (Brown et al., 2011).

In this work, we carry out a detailed analysis of the patterns of expression and the kinetics of translocation of SseK1 into different host cell models. Our data suggest that, under physiological conditions of expression, SseK1 is not translocated upon the initial contact with the eukaryotic cell but when Salmonella is inside the cell. Interestingly, translocation can occur through T3SS1 and/or T3SS2, depending of the host cell type and the time after infection. We also show an SsrB-independent, positive, direct regulation of sseK1 by the two-component system PhoQ/PhoP and identify a PhoP box in the promoter region of SseK1.

\section{Materials and Methods}

\section{Bacterial Strains, Bacteriophages and Strain Construction}

Escherichia coli and S. enterica serovar Typhimurium strains used in this study are described in Table 1. Salmonella strains derive from the mouse-virulent strain ATCC 14028. Transductional crosses using phage P22 HT 105/1 int201 (Schmieger, 1972) were used for strain construction (Maloy, 1990). To obtain phagefree isolates, transductants were purified by streaking on green plates. Green plates were prepared as described (Chan et al., 1972), except that methyl blue (Sigma) substituted for aniline blue. Phage sensitivity was tested by cross-streaking with the clear-plaque mutant P22 H5 (Chan et al., 1972).

\section{Bacterial Culture}

The standard culture medium for S. enterica and E. coli was Luria-Bertani (LB) broth. For SPI1-inducing conditions, S. enterica strains were grown overnight at $37^{\circ} \mathrm{C}$ in $\mathrm{LB}-0.3 \mathrm{M} \mathrm{NaCl}$ medium without shaking. For SPI2-inducing conditions, bacteria were inoculated in low magnesium minimal medium (LPM) at $\mathrm{pH} 5.8$, and incubated overnight at $37^{\circ} \mathrm{C}$ with shaking. LPM contained $80 \mathrm{mM} 2$-( $\mathrm{N}$-morpholino) ethanesulfonic acid (pH 5.8), $5 \mathrm{mM} \mathrm{KCl}, 7.5 \mathrm{mM}\left(\mathrm{NH}_{4}\right)_{2} \mathrm{SO}_{4}, 0.5 \mathrm{mM} \mathrm{K}_{2} \mathrm{SO}_{4}$, $0.1 \%$ casamino acids, $38 \mathrm{mM}$ glycerol, $337.5 \mu \mathrm{M} \mathrm{K} \mathrm{HPO}_{4}{ }^{-}$ $\mathrm{KH}_{2} \mathrm{PO}_{4}$ (pH 7.4), and $8 \mu \mathrm{M} \mathrm{MgCl}_{2}$. For some experiments the concentration of $\mathrm{NaCl}$, of $\mathrm{MgCl}_{2}$, or the $\mathrm{pH}$ of the medium were modified as indicated. Solid media contained $1.5 \%$ agar. Antibiotics were used at the following final concentrations in rich medium: kanamycin $(\mathrm{Km}), 50 \mu \mathrm{g} \mathrm{ml}^{-1}$; chloramphenicol (Cm), $20 \mu \mathrm{g} \mathrm{ml}^{-1}$; ampicillin (Ap), $100 \mu \mathrm{g} \mathrm{ml}^{-1}$; tetracycline $(\mathrm{Tc}), 20 \mu \mathrm{g} \mathrm{ml}^{-1}$. In minimal medium antibiotics were used at these concentrations: kanamycin, $125 \mu \mathrm{g} \mathrm{ml}^{-1}$; chloramphenicol, $5 \mu \mathrm{g} \mathrm{ml}^{-1}$; ampicillin, $50 \mu \mathrm{g} \mathrm{ml}^{-1}$; tetracycline, $10 \mu \mathrm{g} \mathrm{ml}^{-1}$. Plates for monitoring $\beta$-galactosidase activity contained 5-bromo-4-chloro-indolyl- $\beta$-D-galactopyranoside (X-Gal, final concentration, $40 \mu \mathrm{g} \mathrm{ml}^{-1}$ ). $10 \mathrm{mM}$ sodium 
TABLE 1 | Bacterial strains and plasmids used in this study.

\begin{tabular}{|c|c|c|}
\hline Strain/plasmid & Relevant characteristics & Source/reference \\
\hline \multicolumn{3}{|l|}{ Escherichia coli } \\
\hline $\mathrm{DH} 5 \alpha$ & $\begin{array}{l}\text { supE44 } \Delta \text { lacU169 (Ø80 lacZ } \Delta \mathrm{M} 15) \\
\text { hsdR17 recA1 endA1 gyrA96 thi-1 } \\
\text { relA1 }\end{array}$ & Hanahan (1983) \\
\hline XL1-Blue & $\begin{array}{l}\text { recA1 endA1 gyrA96 thi-1 hsdR17 } \\
\text { supE44 relA1 } \Delta \text { lac-pro/F' proAB } \\
\text { lac/q lacZ } \Delta \mathrm{M} 15 \mathrm{Tn} 10\left(\mathrm{Tet}^{\mathrm{r}}\right)\end{array}$ & Bullock et al. (1987) \\
\hline M15 & lac ara gal mtl & Qiagen \\
\hline \multicolumn{3}{|c|}{ Salmonella enterica serovar Typhimuriuma } \\
\hline 14028 & Wild-type & ATCC \\
\hline 55130 & phoQ24 (PhoP constitutive) & E. A. Groisman \\
\hline SV4536 & $\Delta$ dam-230 & Prieto et al. (2004) \\
\hline SV4608 & $\operatorname{trg}::$ MudJ & Segura et al. (2004) \\
\hline SV4699 & phoP7953::Tn10, Tc ${ }^{r}$ & $\begin{array}{l}\text { Groisman et al. } \\
\text { (1989), Segura et al. } \\
\text { (2004) }\end{array}$ \\
\hline SV4757 & $\operatorname{rcsC54}$ & $\begin{array}{l}\text { García-Calderón } \\
\text { et al. (2005) }\end{array}$ \\
\hline SV5049 & $\Delta r c s B:: \mathrm{Cm}^{r}$ & $\begin{array}{l}\text { García-Calderón } \\
\text { et al. (2007) }\end{array}$ \\
\hline SV5373 & $\Delta h i l A$ & J. López-Garrido \\
\hline SV5452 & $\Delta s s r B:: \mathrm{Cm}^{r}$ & $\begin{array}{l}\text { García-Calderón } \\
\text { et al. (2007) }\end{array}$ \\
\hline SV6017 & $\Delta \mathrm{SPI}:: \mathrm{Cm}^{r}$ & $\begin{array}{l}\text { Baisón-Olmo et al. } \\
\text { (2012) }\end{array}$ \\
\hline SV6055 & $\Delta \mathrm{SPI} 1:: \mathrm{Km}^{r}$ & $\begin{array}{l}\text { Baisón-Olmo et al. } \\
\text { (2012) }\end{array}$ \\
\hline SV6402 & $\Delta h i l D:: \mathrm{Cm}^{r}$ & J. López-Garrido \\
\hline SV7070 & $\Delta s s e K 1:: \mathrm{Km}^{\mathrm{r}}$ & This study \\
\hline SV7071 & sseK1::3xFLAG, $\mathrm{Km}^{\mathrm{r}}$ & This study \\
\hline SV7179 & $\Delta s s e K 1$ & This study \\
\hline SV7381 & sseK1::cyaA', Km & This study \\
\hline SV8165 & sseK1::lacZ (translational fusion) & This study \\
\hline \multicolumn{3}{|l|}{ Plasmids } \\
\hline pCE36 & aph FRT lacZY+ this $_{\text {oriR6K }}$ & $\begin{array}{l}\text { Ellermeier et al. } \\
\text { (2002) }\end{array}$ \\
\hline pCE40 & aph FRT 'lacZ lacY' this oriR6K & $\begin{array}{l}\text { Ellermeier et al. } \\
\text { (2002) }\end{array}$ \\
\hline pCP20 & bla cat cl857 $\lambda \mathrm{P}_{\mathrm{R}}$ flp pSC101 oriTS & $\begin{array}{l}\text { Cherepanov and } \\
\text { Wackernagel (1995) }\end{array}$ \\
\hline plC552 & $\begin{array}{l}\text { parent for lacZ transcriptional fusions, } \\
\mathrm{Ap}^{\mathrm{r}}\end{array}$ & Macián et al. (1994) \\
\hline plZ1673 & pSIF003-R1 $\Delta$ lacl & $\begin{array}{l}\text { Cardenal-Muñoz and } \\
\text { Ramos-Morales } \\
\text { (2011) }\end{array}$ \\
\hline plZ1949 & pQE30-phoP & $\begin{array}{l}\text { Cardenal-Muñoz and } \\
\text { Ramos-Morales } \\
(2013)\end{array}$ \\
\hline plZ1959 & plZ1673-SseK1(1-336) & This study \\
\hline plZ2095 & plC552- PsseK1(-500/+40) & This study \\
\hline plZ2112 & $\begin{array}{l}\text { plC552- } \\
\text { PsseK1(-500/+40)TT-73/-72CC }\end{array}$ & This study \\
\hline plZ2115 & pSB377-PsseK1(-500/+40) & This study \\
\hline plZ2135 & $\begin{array}{l}\text { pSB377- } \\
\text { PsseK1(-500/+40)TT-51/-50cC }\end{array}$ & This study \\
\hline plZ2136 & $\begin{array}{l}\text { pSB377- } \\
\text { PsseK1(-500/+40)TT-62/-61CC }\end{array}$ & This study \\
\hline
\end{tabular}

(Continued)
TABLE 1 | Continued

\begin{tabular}{|c|c|c|}
\hline Strain/plasmid & Relevant characteristics & Source/reference \\
\hline plZ2137 & $\begin{array}{l}\text { pSB377- } \\
\text { PsseK1(-500/+40)TT-73/-72CC }\end{array}$ & This study \\
\hline plZ2154 & $\begin{array}{l}\text { plC552- } \\
\text { PsseK1(-500/+40)TT-62/-61, } \\
-73 /-72 \text { CC }\end{array}$ & This study \\
\hline pKD4 & bla FRT aph FRT PS1 PS2 oriR6K & $\begin{array}{l}\text { Datsenko and } \\
\text { Wanner (2000) }\end{array}$ \\
\hline pKD13 & bla FRT aph FRT PS1 PS4 oriR6K & $\begin{array}{l}\text { Datsenko and } \\
\text { Wanner (2000) }\end{array}$ \\
\hline pKD46 & bla $\mathrm{P}_{\mathrm{BAD}}$ gam bet exo pSC101 oriTs & $\begin{array}{l}\text { Datsenko and } \\
\text { Wanner (2000) }\end{array}$ \\
\hline pREP4 & $\mathrm{lacl}, \mathrm{Km}^{\mathrm{r}}$ & Qiagen \\
\hline pSB377 & $\begin{array}{l}\text { parent for luxCDABE transcriptional } \\
\text { fusions, } \mathrm{Ap}^{r}\end{array}$ & Winson et al. (1998) \\
\hline
\end{tabular}

a Derivatives of these strains were used as indicated in the text.

butyrate (Sigma) was added to the medium in some experiments.

\section{Mammalian Cell Culture}

HeLa (human epithelial; ECAC no. 93021013), RAW264.7 (murine macrophages; ECACC no. 91062702), NRK-49F (normal rat kidney fibroblasts; ATCC CRL-1570), Cos-7 (monkey fibroblasts; ATCC CRL-1651), NIH3T3 (murine fibroblasts; ATCC CRL-1658), J774A.1 (murine macrophages; ATCC TIB67) and Caco2 (human epithelial; ATCC HTB-37) cells were cultured in DMEM supplemented with $10 \%$ fetal calf serum and $2 \mathrm{mM}$ L-glutamine. Sixty $\mu \mathrm{g} \mathrm{ml}^{-1}$ penicillin, and $100 \mu \mathrm{g} \mathrm{ml}^{-1}$ streptomycin were included in the culture media (except for bacterial infection experiments). All cells were maintained in a 5\% $\mathrm{CO}_{2}$ humidified atmosphere at $37^{\circ} \mathrm{C}$.

\section{DNA Amplification with the Polymerase Chain Reaction and Sequencing}

Amplification reactions were carried out in a T100 Thermal Cycler (Bio-Rad). The final volume of reactions was $50 \mu \mathrm{l}$, and the final concentration of $\mathrm{MgCl}_{2}$ was $1.5 \mathrm{mM}$. Reagents were used at the following concentrations: dNTPs, $300 \mu \mathrm{M}$; primers, $0.3 \mu \mathrm{M}$; and Taq polymerase (KAPA HiFi DNA Polymerase, Kapa Biosystems), 1 unit per reaction. The thermal program included the following steps: (i) initial denaturation, $3 \mathrm{~min}$ at $95^{\circ} \mathrm{C}$; (ii) 25 cycles of denaturation $\left(98^{\circ} \mathrm{C}, 20 \mathrm{~s}\right)$, annealing $\left(60^{\circ} \mathrm{C}, 15 \mathrm{~s}\right)$, and extension $\left(72^{\circ} \mathrm{C}, 30 \mathrm{~s}\right.$ per kb); and (iii) final incubation at $72^{\circ} \mathrm{C}$ for $5 \mathrm{~min}$, to complete extension. To generate directed mutations in the sseK1 promoter cloned in PSB377 or pIC552 the thermal program included the following steps: (i) initial denaturation, $3 \mathrm{~min}$ at $95^{\circ} \mathrm{C}$; (ii) 17 cycles of denaturation $\left(98^{\circ} \mathrm{C}, 20 \mathrm{~s}\right.$ ), annealing $\left(62^{\circ} \mathrm{C}, 15 \mathrm{~s}\right)$, and extension $\left(72^{\circ} \mathrm{C}, 6 \mathrm{~min}\right)$; (iii) final extension at $72^{\circ} \mathrm{C}$ for $5 \mathrm{~min}$. Primers are listed in Table 2. PCR constructs were sequenced with an automated DNA sequencer (Stab Vida, Oeiras, Portugal).

\section{Plasmids}

Plasmids used in this study are listed in Table 1. Plasmid pIZ2115 expressing a transcriptional sseK1::lux fusion was 
TABLE 2 | Oligonucleotides used in this study.

\begin{tabular}{|c|c|}
\hline Oligonucleotide/use & Sequence $5^{\prime}-3^{\prime}$ \\
\hline \multicolumn{2}{|l|}{ sseK1 deletion } \\
\hline sseK1dP1 & $\begin{array}{l}\text { TAAAATATGTAATGAAGTAAGTATGGAGCA } \\
\text { TITAATTGTTGTGTAGGCTGGAGCTGCTTC }\end{array}$ \\
\hline sseK1dP2 & $\begin{array}{l}\text { ATATTITATGTATTCAATAGCATGATTATTGCCA } \\
\text { ПTTCCGCATATGAATATCCTCCTTAG }\end{array}$ \\
\hline \multicolumn{2}{|c|}{ Construction of sseK1::lacZ translational fusion } \\
\hline sseK1P1b & $\begin{array}{l}\text { CATGAACTITGCGTAAACTGACTGGTATTCATT } \\
\text { ATAATGTGTGTAGGCTGGAGCTGCTTC }\end{array}$ \\
\hline sseK1P4 & $\begin{array}{l}\text { ATATGTTCCCGCGCTTTCAAAAAATGAATTGGTT } \\
\text { AAAACTATTCCGGGGATCCGTCGACC }\end{array}$ \\
\hline \multicolumn{2}{|c|}{ Epitope tagging of SseK1 } \\
\hline sseK1P1flag & $\begin{array}{l}\text { CAGTCAGTTACGCAAAGTTCATGGGCGAGGCAT } \\
\text { GTGCAGGACTACAAAGACCATGACGG }\end{array}$ \\
\hline sseK1P2flag & $\begin{array}{l}\text { ATATTTATGTATTCAATAGCATGATTATTGC } \\
\text { CATTCCGCATATGAATATCCTCCTTAG }\end{array}$ \\
\hline \multicolumn{2}{|c|}{ Chromosomal sseK1::cyaA' fusion } \\
\hline sseK1P1 & $\begin{array}{l}\text { CAGTCAGTTACGCAAAGTTCATGGGCGAGGCA } \\
\text { TGTGCAGCTGCAGCAATCGCATCAGGC }\end{array}$ \\
\hline sseK1P2 & $\begin{array}{l}\text { ATATITATGTATTCAATAGCATGATTATTGCCAT } \\
\text { TTCCGTTAGAAAAACTCATCGAGCATC }\end{array}$ \\
\hline \multicolumn{2}{|c|}{ Verification of chromosomal sseK1::cyaA' fusion } \\
\hline sseK1E1 & TTAATTGCTCACTGGCAGGG \\
\hline SseK1E2 & GCACTGCGATITIAAAGTGG \\
\hline cyaArev & CCTTGATGCCATCGAGTACG \\
\hline \multicolumn{2}{|c|}{ Construction of plZ1959 } \\
\hline sseK1BampSIFfw & $\begin{array}{l}\text { AGTCGGATCCAGGAGGAAATAT } \\
\text { ATGATCCCACCATTAAATAG }\end{array}$ \\
\hline sseK1BampSIFrev & $\begin{array}{l}\text { GATCGGATCCACTGCACATG } \\
\text { CCTCGCCCATG }\end{array}$ \\
\hline \multicolumn{2}{|c|}{ Construction of plZ2095 } \\
\hline PsseK1-500fwBgl & AGTCAGATCTTTGGGACAATTACATTATG \\
\hline PsseK1+40revXho & AGTCCTCGAGAACAATTAAATGCTCCATAC \\
\hline \multicolumn{2}{|c|}{ Construction of plZ2115 } \\
\hline PsseK1-500fwEco & AGTCGAATTCTTGGGACAATTACATTATG \\
\hline PsseK1+40revEco & AGTCGAATTCAACAATTAAATGCTCCATAC \\
\hline \multicolumn{2}{|c|}{ Construction of plZ2135 } \\
\hline sseK1TT-51CCfw & GCTTAGTTAGCATCTTCCAGCTGACAGCGATTGC \\
\hline sseK1TT-51CCrev & GCAATCGCTGTCAGCTGGAAGATGCTAAACTAAGC \\
\hline \multicolumn{2}{|c|}{ Construction of plZ2136 } \\
\hline sseK1TT-62CCfw & $\begin{array}{l}\text { CCTCCGGTTAATGCTTAGCCTAGCATC } \\
\text { TITAGCTGAC }\end{array}$ \\
\hline sseK1TT-62CCrev & $\begin{array}{l}\text { GTCAGCTAAAAGATGCTAGGCTAAGCATT } \\
\text { AACCGGAGG }\end{array}$ \\
\hline \multicolumn{2}{|c|}{ Construction of plZ2112 and pIZ2137 } \\
\hline sseK1TT-73CCfw & $\begin{array}{l}\text { GTATTATGTATCCTCCGGCCAATGCTTAGT } \\
\text { TTAGCATC }\end{array}$ \\
\hline sseK1T-73CCrev & $\begin{array}{l}\text { GATGCTAAACTAAGCATTGGCCGGAGGATAC } \\
\text { ATAAATAC }\end{array}$ \\
\hline \multicolumn{2}{|l|}{ Construction of plZ2154 } \\
\hline sseK1-73T-62CCfw & $\begin{array}{l}\text { CCTCCGGCCAATGCTTAGCCTAGCATCTTT } \\
\text { TAGCTGAC }\end{array}$ \\
\hline sseK1-73TT-62CCrev & $\begin{array}{l}\text { GTCAGCTAAAAGATGCTAGGCTAAGCATTGG } \\
\text { CCGGAGG }\end{array}$ \\
\hline \multicolumn{2}{|l|}{ sseK1 promoter } \\
\hline FAMsseK1-500fw & TTGGGACAATTACATTATGTTTG \\
\hline FAMsseK1+4Orev & AАCAATTAAATGCTCCATACTTAC \\
\hline
\end{tabular}

(Continued)
TABLE 2 | Continued

\begin{tabular}{ll}
\hline Oligonucleotide/use & Sequence $\mathbf{5}^{\prime} \mathbf{- \mathbf { 3 } ^ { \prime }}$ \\
\hline FAMsseK1-300fw & CTCGCCATTATAAAATACCTG \\
FAMsseK1-1rev & CATGATGATTATAGCACATG \\
slyB promoter & \\
promslyBdir & AGACTTGCCTGTTGCGCAAC \\
promslyBrev & AAACGCTATTCAGCATCCC \\
phoN promoter & \\
promphoNdir & AATGCGTGTCAGTCAGGCAC \\
promphoNrev & TTAGCTACGATCAGTGGTAG \\
\hline
\end{tabular}

a derivative of pSB377 (a generous gift from P. Williams, University of Nottingham). To construct this plasmid, DNA from strain 14028 was used as a template for PCR amplification with the primers listed in Table 2. The amplified fragments were digested with EcoRI and ligated with EcoRI-digested pSB377. To generate point mutations in the sseK1 promoter, pIZ2095 or pIZ2115 were used as templates for PCR amplification using primer pairs sseK1TT-51CCfw/sseK1TT-51CCrev, sseK1TT-62CCfw/sseK1TT-62CCrev, sseK1TT-73CCfw/sseK1 TT-73CCrev, or sseK1-73TT-62CCfw/sseK1-73TT-62CCrev. Products were digested with $1 \mu \mathrm{l}$ of $D p n \mathrm{I}\left(10 \mathrm{U} \mu \mathrm{l}^{-1}\right)$ for $1 \mathrm{~h}$ at $37^{\circ} \mathrm{C}$ and used to transform E. coli $\mathrm{DH} 5 \alpha$. All constructs were confirmed by DNA sequencing.

\section{Generation of a sseK1 Mutant}

Disruption and replacement of sseK1 with a $\mathrm{Km}$ resistance gene were performed as described previously (Datsenko and Wanner, 2000). Briefly, the Km resistance gene from plasmid pKD4 was PCR amplified with primers sseK1dP1 and sseK1dP2 (Table 2). The PCR product was used to transform the wildtype strain carrying the Red recombinase expression plasmid pKD46.

\section{Construction of lacZ, 3xFLAG, and cyaA' Chromosomal Fusions}

The Km resistance gene from plasmid pKD13 was PCR amplified with primers sseK1P1b and sseK1P4 (Table 2). The PCR product was used to transform the wild-type strain carrying the Red recombinase expression plasmid pKD46. The antibiotic resistance cassette introduced by the gene-targeting procedure described in the previous section was eliminated by recombination using the FLP helper plasmid pCP20 (Datsenko and Wanner, 2000). The FRT site generated by excision of the antibiotic resistance cassette was used to integrate plasmid pCE40 to generate a translational lac fusion (Ellermeier et al., 2002). Addition of a DNA fragment encoding the $3 \times$ FLAG epitope tag at the $3^{\prime}$ end of sseK1 was carried out as described (Uzzau et al., 2001) using primers sseK1P1flag and sseK1P2flag. The protocol to generate a chromosomal sseK1::cyaA' translational fusion was recently described (Ramos-Morales et al., 2015).

\section{$\beta$-Galactosidase Assays}

Levels of $\beta$-galactosidase were assayed as described (Miller, 1972), using the $\mathrm{CHCl}_{3} / \mathrm{SDS}$ permeabilization procedure. Bacteria 
were grown under SPI1 or SPI2-inducing conditions or modifications of these conditions as described in Section "Results."

\section{Antibodies and Immunoblot}

Salmonella strains were grown under different conditions. Usually, cultures in LB medium were diluted and grown in different media. The bacteria were then pelleted by centrifugation and resuspended in sodium dodecyl sulfate-polyacrylamide gel electrophoresis (SDS-PAGE) sample buffer. Proteins from the same numbers of bacteria were separated by gradient SDS-PAGE (Mini-PROTEAN TGX precast gels, 4-15\%) and electrophoretically transferred to nitrocellulose filters for Western blot analysis using anti-Flag (M2) monoclonal antibodies (1:5000; Sigma), and anti-DnaK (8E2/2) monoclonal antibodies (1:5000; Assay Designs). Goat anti-mouse HRPconjugated antibodies (1:5000; BioRad) and goat anti-rabbit HRP-conjugated antibodies (1:10000; GE Healthcare) were used as secondary antibodies. Intensities of SseK1-3xFLAG and DnaK bands were quantified using NIH ImageJ $1.42 \mathrm{q}$ software.

\section{Virulence Assays in Mice}

Groups of three 8-weeks-old female BALB/c mice (Charles River Laboratories) were inoculated with a 1:1 ratio of two strains of S. enterica serovar Typhimurium: a $\Delta$ sseK $1:: \mathrm{Km}^{\mathrm{r}}$ null mutant and the wild-type (strain 14028). For oral inoculation, bacterial cultures were grown overnight at $37^{\circ} \mathrm{C}$ in $\mathrm{LB}$ without shaking. For intraperitoneal inoculation, bacteria were grown overnight at $37^{\circ} \mathrm{C}$ in $\mathrm{LB}$ with shaking, diluted into fresh medium (1:100), and grown to an $\mathrm{OD}_{600}$ of $0.3-0.6$. Oral inoculation was performed by feeding the mice with $25 \mu \mathrm{l}$ of $0.9 \% \mathrm{NaCl}$ containing $0.1 \%$ lactose and $10^{8} \mathrm{CFU}$. Intraperitoneal inoculation was performed with $0.2 \mathrm{ml}$ of $0.9 \% \mathrm{NaCl}$ containing $10^{5}$ CFU. Bacteria were recovered from spleens 6 days (oral) or 2 days (intraperitoneal) after inoculation and colonies were enumerated on LB and LB with $\mathrm{Km}$ (to distinguish mutant and wild-type strains). A competitive index (CI) was calculated as the ratio between the sseK 1 mutant and the wild-type strain in the output (bacteria recovered from spleens) divided by their ratio in the input (initial inoculum). The experimental protocol was approved by the ethical committee of the University of Seville.

\section{Bacterial Infections of Cultured Cells}

Mammalian cells were plated $24 \mathrm{~h}$ before infection in 24-well plates (Thermo Scientific) at $1.5 \times 10^{5}$ cells per well, and incubated at $37^{\circ} \mathrm{C}$ with $5 \% \mathrm{CO}_{2}$ in media without antibiotics. For infections under SPI1-inducing (invasive) conditions, bacteria grown overnight in LB- $0.3 \mathrm{M} \mathrm{NaCl}$ in a tightly closed tube without shaking were added at a multiplicity of infection of 100 . For infections of mammalian cells under non-invasive conditions, bacteria were grown in LB for $24 \mathrm{~h}$ at $37^{\circ} \mathrm{C}$ with shaking. Bacteria were centrifuged onto the cell monolayer at $200 \mathrm{~g}$ for $5 \mathrm{~min}$ and then incubated at $37^{\circ} \mathrm{C}$ with $5 \% \mathrm{CO}_{2}$. The cell culture was washed twice with phosphate-buffered saline (PBS) $1 \mathrm{~h}$ post-infection (p.i.), overlaid with DMEM containing $100 \mu \mathrm{g} \mathrm{ml}^{-1}$ gentamicin, and incubated for $1 \mathrm{~h}$. The culture was then washed twice with PBS, covered with DMEM with gentamicin $16 \mu \mathrm{g} \mathrm{ml}^{-1}$, and incubated for 2-14 h.

For invasion and proliferation assays, infections were carried out using a 10:1 mix of the sseK1 mutant and a $\operatorname{trg}:: \mathrm{Mu} d \mathrm{~J}$ mutant (wild-type for invasion and intracellular proliferation but $\mathrm{Lac}^{+}$ due to the MudJ insertion). CI for invasion and proliferation were calculated as previously described (Segura et al., 2004) after plating appropriate dilutions and enumerating white colonies (sseK1) and blue colonies (trg::MudJ) in LB plates supplemented with $40 \mu \mathrm{g} \mathrm{ml}^{-1}$ 5-bromo-4-chloro-galactopyranoside (X-Gal). For invasion, the input was the initial mix of bacteria used in the infection and the output bacteria recovered $2 \mathrm{~h}$ p.i. For intracellular proliferation, bacteria were recovered $1.25 \mathrm{~h}$ p.i. (input) and 24 h p.i. (output).

\section{Bioluminescence Assays}

Bacterial strains were grown under SPI1 or SPI2-inducing conditions. Samples of $150 \mu \mathrm{l}$ were transferred into white, clear bottom, 96-well plates (Corning) and luminescence and $\mathrm{OD}_{600}$ were read using a Synergy HT microplate reader (BioTek). Conditions used for reading luminescence were: read type, endpoint; integration time, $1 \mathrm{~s}$; emission, hole; position, top; sensitivity, 150. To measure luminescence of intracellular bacteria, RAW264.7 cells were plated into white, clear bottom, 96-well plates at $3 \times 10^{4}$ cells per well, and were infected $24 \mathrm{~h}$ later with noninvasive bacteria, according to the protocol described in Section "Bacterial Infections of Cultured Cells." Luminescence was measured 2, 4, and $8 \mathrm{~h}$ p.i. and the numbers of CFU per well were calculated after incubation with $1 \%$ Triton X-100 in PBS for $10 \mathrm{~min}$ at $37^{\circ} \mathrm{C}$ to release bacteria, plating appropriate dilutions in $\mathrm{LB}$ with $\mathrm{Ap}$, and counting colonies after $24 \mathrm{~h}$ of incubation at $37^{\circ} \mathrm{C}$.

\section{Protein Translocation Assay}

Following the infections described above, the translocation of the SseK1-CyaA' fusion into the eukaryotic cells was monitored by measuring the levels of cAMP. The infected cells were lysed and the level of cAMP in the lysates was determined using a colorimetric direct cAMP enzyme immunoassay kit (Arbor Assays) according to the manufacturer's instructions.

\section{Protein Purification and Phosphorylation}

$\mathrm{His}_{6}$-PhoP protein was produced and purified as previously described (Gal-Mor et al., 2011) with some modifications (Cardenal-Muñoz and Ramos-Morales, 2013). For binding assays, S. enterica $\mathrm{His}_{6}$-PhoP was phosphorylated with acetyl phosphate as previously described (Tang et al., 2012) with modifications. Briefly, $\mathrm{His}_{6}$-PhoP was incubated in $20 \mu \mathrm{l}$ of phosphorylation buffer $(50 \mathrm{mM}$ Tris- $\mathrm{HCl} \mathrm{pH} 7.5,50 \mathrm{mM} \mathrm{KCl}, 10 \mathrm{mM}$ $\mathrm{MgCl}_{2}$ ) containing $10 \mathrm{mM}$ acetyl phosphate (Sigma-Aldrich) for $1 \mathrm{~h}$ at $37^{\circ} \mathrm{C}$.

\section{Electrophoretic Mobility Shift Assay (EMSA)}

DNA fragments used for the PhoP binding assay were amplified by PCR using Salmonella 14028 as a template. The primers, listed in Table 2, were labeled with 6-carboxyfluorescein (FAM). 
PCR amplification rendered fragments of 281, 355, and 540 (or 300) bp for phoN, slyB, and sseK1 promoters, respectively. The binding assay was carried out as previously described (Tang et al., 2012) with modifications. Briefly, a solution of $5 \mathrm{nM}$ of FAM-labeled DNA and $0,0.125,0.25,0.5,1$, and $2 \mu \mathrm{M}$ of phosphorylated $\mathrm{His}_{6}$-PhoP was prepared in binding buffer (50 mM Tris- $\mathrm{HCl} \mathrm{pH} \mathrm{8.0,50} \mathrm{mM} \mathrm{KCl}$ ) in a total volume of $20 \mu \mathrm{l}$ and incubated for $30 \mathrm{~min}$ at room temperature. ProteinDNA complexes were subjected to electrophoresis at $4^{\circ} \mathrm{C}$ in a $6 \%$ non-denaturing acrylamide:bisacrylamide (29:1) gel in $0.5 \mathrm{X}$ Tris-borate-EDTA buffer. Images were acquired using a Fujifilm FLA-5100 system.

\section{Statistical Analysis}

Student's $t$-test was used to analyze differences in $\beta$-galactosidase activities and light emission. This test was also used to analyze every CI against the null hypothesis that the mean is not significantly different from 1. $P$ values of 0.05 or less were considered significant.

\section{Results}

\section{Contribution of SseK1 to Virulence in Mice}

The role of SseK1 and SseK2 in virulence was previously evaluated by infecting BALB/c mice with sseK1, sseK2 or sseK1 sseK2 mutants, but no attenuation was detected using a time to death assay after intraperitoneal infections (Kujat Choy et al., 2004). More recently, a sensitive method, the CI, revealed significant attenuation of the sseK 1 sseK 2 sseK 3 triple mutant and of the sseK1 sseK2 double mutant, but no attenuation of the sseK3 single mutant, after oral infections (Brown et al., 2011). These results prompted us to analyze the specific contribution of SseK1 to Salmonella virulence. An sseK1 null mutant was generated and the CI for this single mutant compared to the wild-type strain ( $S$. enterica serovar Typhimurium strain 14028). Significant attenuation $(P<0.05)$ was observed both after intraperitoneal and after oral infections of $\mathrm{BALB} / \mathrm{c}$ mice
(Figure 1A). Specific contribution of SseK1 to invasion and intracellular proliferation was assessed calculating the CI of the sseK1 mutant against the $\operatorname{trg}:: \mathrm{Mud}$ J strain [wild-type for invasion and intracellular proliferation (Segura et al., 2004)] in a variety of mammalian cell types: HeLa (human epithelial), NRK49F (rat fibroblasts), RAW264.7 (murine macrophages), Cos-7 (monkey fibroblasts), 3T3 (murine fibroblasts), J774.A1 (murine macrophages), and Caco2 (human epithelial). No significant defect was detected for this mutant $(P>0.05$; Figures 1B,C). Together, the results shown in this section suggest that SseK1 is necessary for full virulence of Salmonella in mice but that it does not contribute specifically to invasion or intracellular proliferation, at least in the cell types and under the conditions tested.

\section{Synthesis and Translocation into Mammalian Cells of SseK1 Under SPI1 and SPI2 Inducing Conditions}

Although expression and secretion to culture media of SseK1 was detected under SPI1 and SPI2-inducing conditions, this Salmonella effector was described as translocated into human epithelial HeLa cells specifically through the T3SS2 (Kujat Choy et al., 2004). These previous results were obtained based on SseK1-2HA and SseK1-CyaA' fusions expressed from a plasmid. To carry out a more detailed analysis of the expression of sse K1, we constructed a chromosomal lac $Z$ translational fusion in the native sseK 1 locus. This fusion permits quantification of the physiological levels of expression of this gene by measuring $\beta$-galactosidase activities (see Materials and Methods). As seen in Figure 2A, sseK1 was expressed under SPI1-inducing conditions ( $\mathrm{LB}, 0.3 \mathrm{M} \mathrm{NaCl}$, without aeration) but its expression was significantly higher $(P<0.01)$ under SPI2-inducing conditions (LPM, pH 5.8, high aeration). Variants of these conditions were tested to detect relevant factors influencing the expression of sseK1. Changes in osmolarity in the SPI1-inducing medium had little but significant impact $(P<0.01$ or 0.05 ; Figure $2 B$ ), and the maximum expression in this medium was obtained

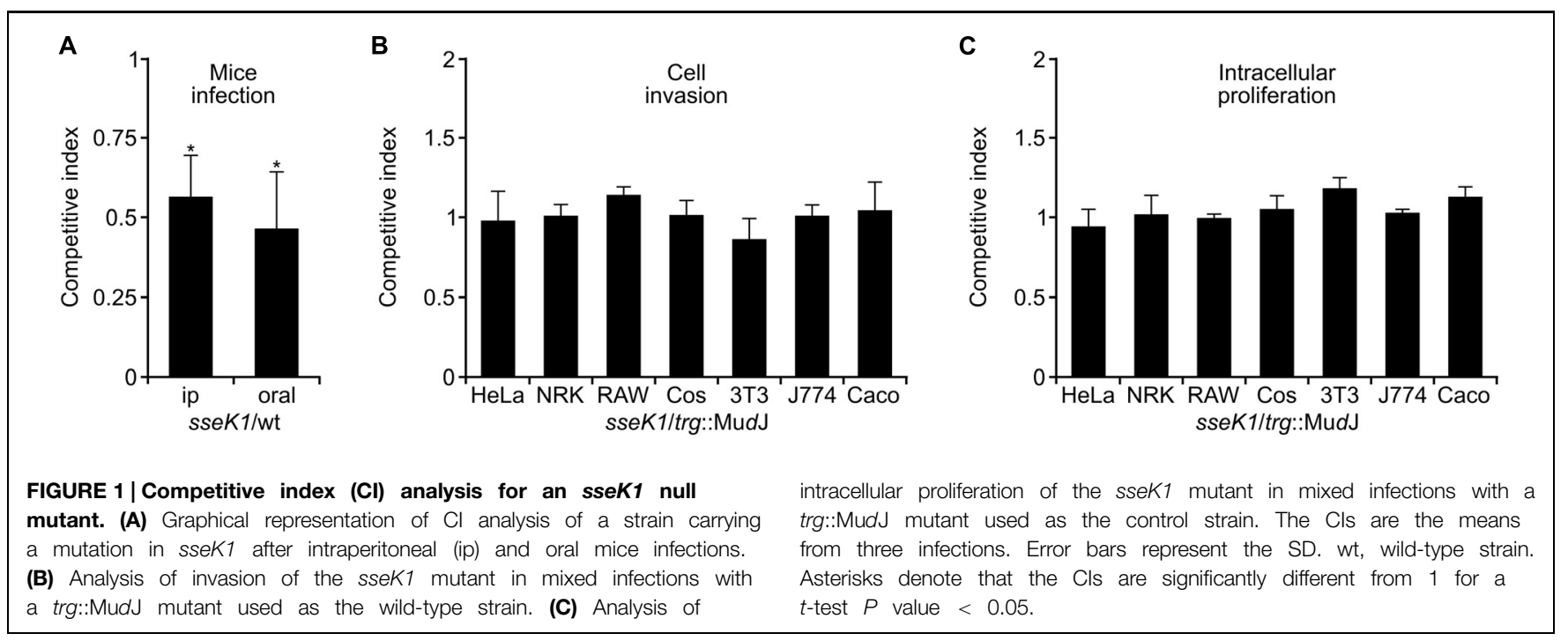




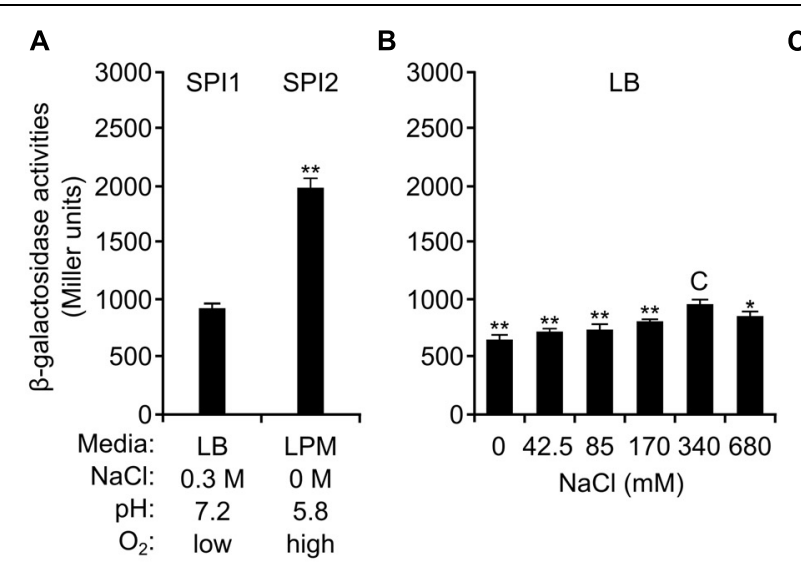

FIGURE 2 | Expression of sseK1 in different culture media. $\beta$-Galactosidase activities were measured from overnight cultures of a Salmonella enterica strain carrying a chromosomal sseK1::/acZ translational fusion. (A) Bacteria were incubated overnight at $37^{\circ} \mathrm{C}$ in $\mathrm{LB}$ with $0.3 \mathrm{M} \mathrm{NaCl}$ without shaking (SPI1) or in LPM with shaking (SPI2). (B) Different concentrations of $\mathrm{NaCl}$ were used to test the role of osmolarity on sseK1 expression under SPI1-inducing

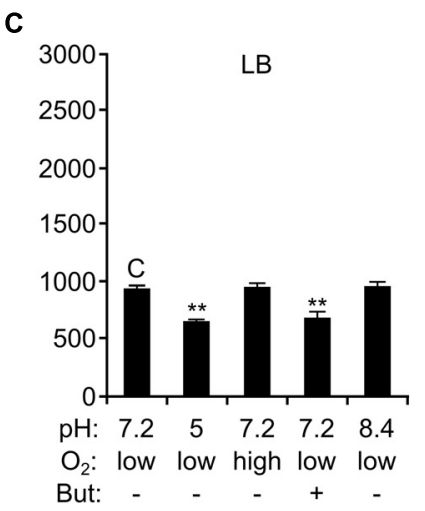

conditions. (C) The effects of $\mathrm{pH}$, oxygen limitation and butyrate on sseK1 expression were tested in LB. (D) Activities were measured after growth in LPM with different $\mathrm{pH}$ and $\mathrm{Mg}^{++}$concentrations, as indicated. Means and SD from three independent $\beta$-galactosidase measurements are shown. Statistical significance is shown by asterisks representing $t$-test $P$ values: ${ }^{*} P<0.05 ;{ }^{*} P<0.01$. C: reference for statistical comparison. with the original $\mathrm{NaCl}$ concentration $(0.3 \mathrm{M})$. Hypoxia did not appear to be an important factor in the expression of sseK1 but butyrate, a fermentation product found in the intestine that is known to downregulate SPI1 genes, caused a significant repression $(P<0.01)$ of sseK1 expression (Figure 2C). Interestingly, although the low $\mathrm{Mg}^{++}$concentration that is present in the medium used to induce SPI2 (LPM) was a factor contributing to expression of sseK1, the acidic $\mathrm{pH}$ of the same medium had a negative impact (Figure 2D) and the highest expression was observed in LPM with low $\mathrm{Mg}^{++}$concentration at $\mathrm{pH} 8.4(P<0.01)$. A general conclusion of these experiments is that expression of sseK1 is not restricted to SPI1- or SPI2inducing conditions resulting in coexpression of this gene with both islands.

The results shown above are compatible with translocation of SseK1 through T3SS1 and T3SS2. A detailed analysis of this possibility was carried out using two kinds of SseK1-CyaA' fusions: the first one was prepared in a plasmid and its expression was driven by a constitutive promoter; the second one was generated in the chromosome under the control of the native promoter. In both cases the whole SseK1 protein was fused to the catalytic domain of the calmodulin-dependent adenylate cyclase from Bordetella pertussis. Salmonella strains (wild-type and mutants lacking T3SSs) expressing these fusions were used to infect three mammalian cell types: human epithelial HeLa cells, murine RAW264.7 macrophages and rat NRK-49F fibroblasts. Translocation of the fusion into host cells was tested $1,2,4,8$, and $16 \mathrm{~h}$ p.i. and was detected as an increase in cAMP concentration in the cell culture (Figure 3). All the infections were carried out using invasive bacteria (grown under SPI1-inducing conditions) except long infections (4-16 h) of RAW cells to prevent rapid macrophage pyroptosis induced by invasive bacteria (Fink and Cookson, 2007). Interestingly, different patterns of translocation were observed depending on the host cell and on the fusion. The main conclusions are: (i) Translocation of SseK1 at short times ( 1 and $2 \mathrm{~h}$ p.i.) is only observed when the fusion is constitutively expressed from a plasmid (Figures 3A,C,E) and is dependent on T3SS 1 in the three cell types. (ii) When sseK 1 is expressed from its own promoter (Figures 3B,D,F), translocation of SseK1 starts at $4 \mathrm{~h}$ p.i. in epithelial cells and fibroblasts, and at $8 \mathrm{~h}$ p.i. in macrophages. Under these conditions, translocation into HeLa cells depends on T3SS1, translocation into RAW cells depends on T3SS2, and translocation into NRK cells occurs through both systems.

\section{SsrB Independent Regulation of sseK1 by PhoQ/PhoP}

We took advantage of the chromosomal sseK1::lacZ fusion to look for genetic factors controlling sseK1 expression. We tested the effect of mutations in genes encoding important virulence regulators: HilA, HilD, SsrB, PhoP, RcsB, and Dam. HilA and HilD are positive regulators of SPI1 (Bajaj et al., 1995; Schechter and Lee, 2001). SsrB is the main positive regulator of the expression of SPI2 (Cirillo et al., 1998). Both islands are regulated by $\mathrm{PhoP}$, that positively regulates SPI2 through SsrB and negatively regulates SPI1 through HilA (Bajaj et al., 1996; Bijlsma and Groisman, 2005). RcsB represses SPI1 through HilD (Mouslim et al., 2004; Lin et al., 2008). Dam is an adenine methylase that activates SPI1 through HilD (LópezGarrido and Casadesús, 2010). In addition to null mutations in all these genes, the point mutations phoQ24 and $r c s C 54$ were also used. These mutations result in constitutive activation of the two-component system PhoQ/PhoP and of the phosphorelay system $\mathrm{RcsC} / \mathrm{RcsD} / \mathrm{RcsB}$, respectively. The level of expression of sseK1::lacZ was measured in liquid bacterial cultures grown under SPI1 (Figure 4A) or SPI2 (Figure 4B) inducing conditions. The results suggest that $\mathrm{PhoP}$ is a positive regulator of sseK1 expression since a significant decrease 


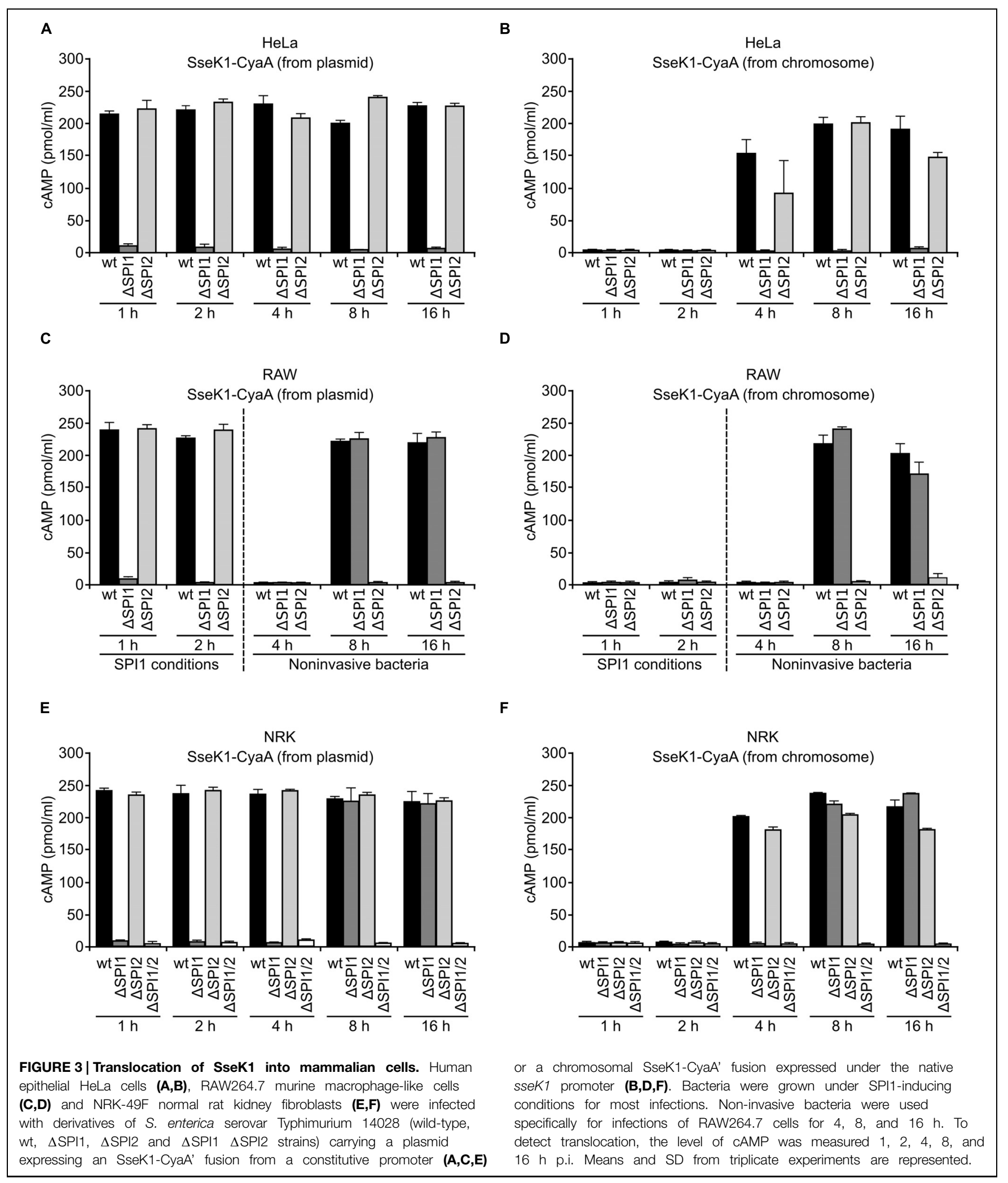

in expression was observed in a phoP-null mutant under SPI2 inducing conditions $(P<0.01)$. This conclusion is confirmed by the positive effect of the activating mutation phoQ24 on
sseK1 expression under SPI1-inducing conditions $(P<0.05)$. We also assessed the effect of the phoP mutation on SseK1 at the protein level using a chromosomal 3xFLAG fusion 


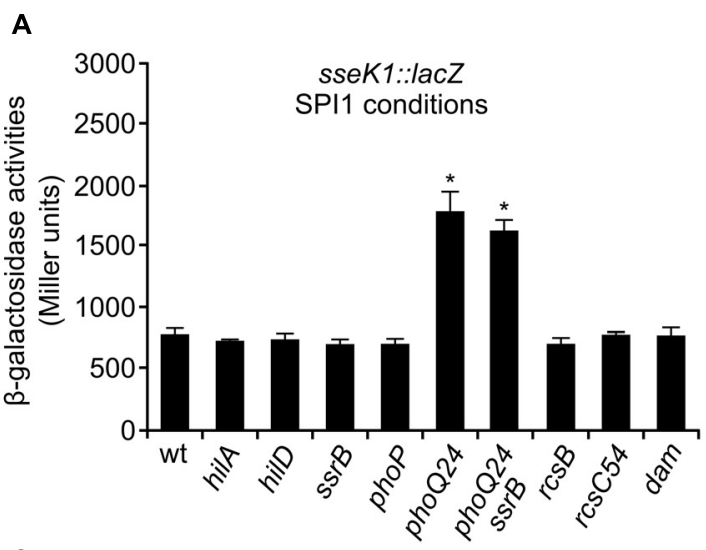

C
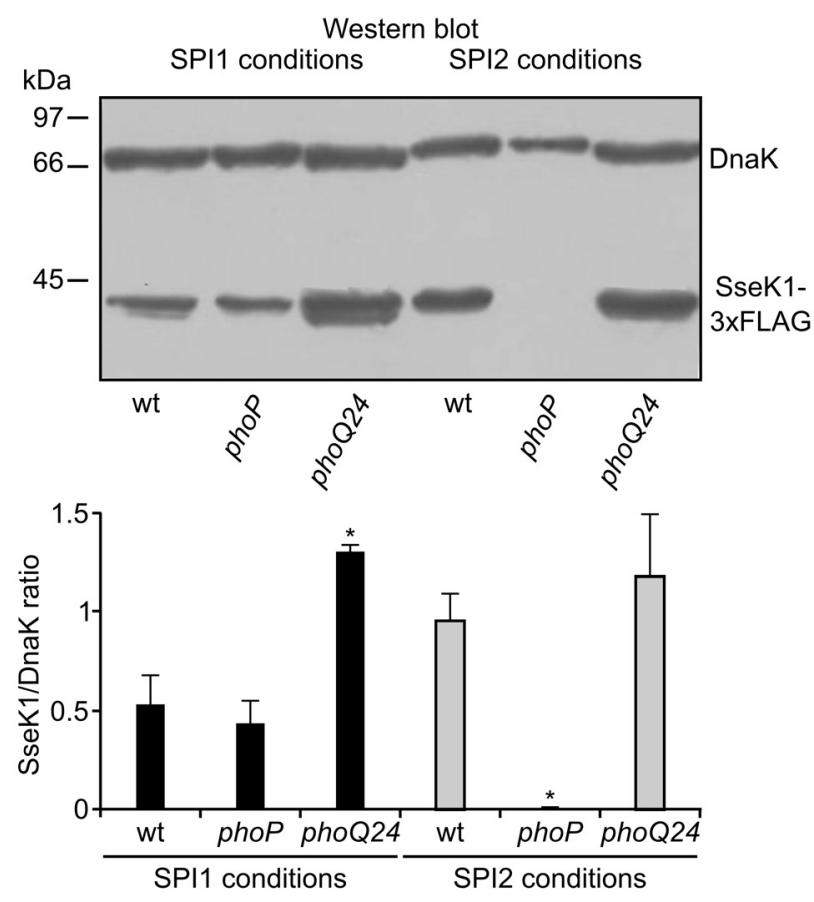

FIGURE 4 | Positive regulation of the expression of sseK1 by the PhoQ/PhoP system. $\beta$-Galactosidase activities were measured from SPI1-inducing (A) and SPI2-inducing (B) cultures of several S. enterica serovar Typhimurium strains: wild-type 14028 (wt), null mutants (hilA, hilD, ssrB, rcsB, and dam), and mutants with constitutive activation of the PhoQ/PhoP system and the Rcs system, respectively (phoQ24 and rcsC54), carrying an sseK1::/acZ translational fusion. The role of SsrB in the regulation by PhoP was investigated in a double mutant phoQ24 ssrB. Means and SD from three independent

B

D
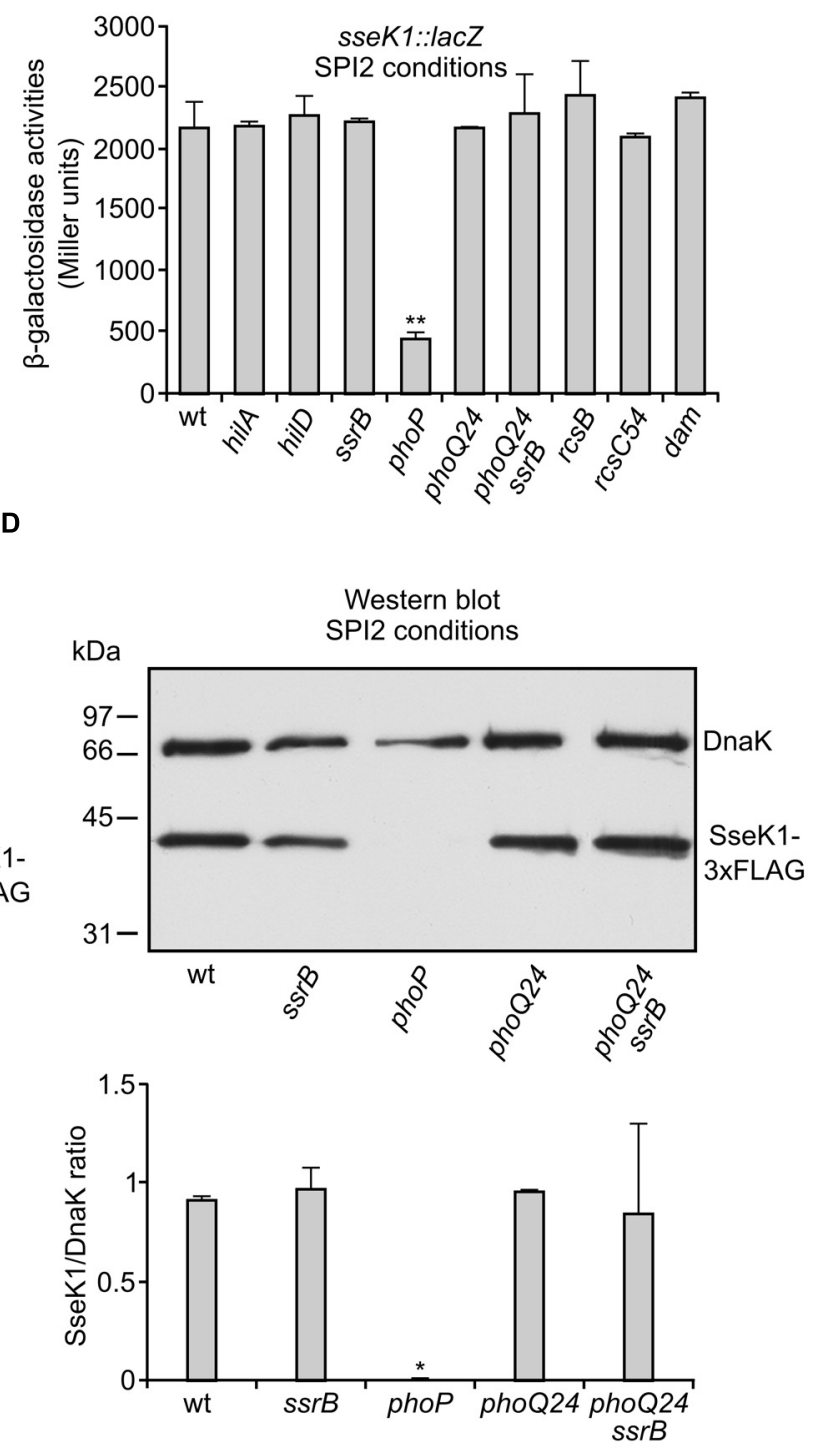

$\beta$-galactosidase measurements are shown. The effect of the PhoQ/PhoP system (C) and of SsrB (D) on sseK1 expression at the protein level was assessed by immunoblot analysis using strains expressing SseK1-3xFLAG. A monoclonal anti-FLAG antibody was used to detect the fusion protein and a polyclonal anti-DnaK antibody was used to get a loading control. Representative gels are shown together with quantification of bands (SseK1/DnaK ratio) from duplicate gels. Statistical significance of the differences between wt and mutant strains is shown by asterisks representing $t$-test $P$ values: ${ }^{*} P<0.05$; ${ }^{*} P<0.01$.
(Figure 4C). The effect was more dramatic at this level suggesting some kind of postranslational regulation in addition to the modulation of transcription that is expected for PhoP. No effect was detected for mutations affecting the other regulators that were tested in these assays, including SsrB. Lack of SsrB had no significant impact on sseK1 expression even in a phoQ24 background (Figure 4D), providing evidence for SsrB-independent upregulation of sseK1 by the PhoQ/PhoP system.

\section{Direct Regulation of sseK1 Expression by PhoP}

Next, we reasoned that since PhoP regulates sseK1 in an SsrBindependent manner, it could be a direct regulator of this gene. To test this possibility, we decided to analyze the promoter region of sseK1 looking for a putative PhoP-binding site. According to a previous global analysis carried out on S. enterica serovar Typhimurium strain SL1344 (Kroger et al., 2012), the transcriptional start site of sseK 1 is a $\mathrm{T}$ located 40 nucleotides 
upstream of the translational start codon. Visual inspection revealed the presence of putative -10 and -35 consensus motifs for 670 -dependent transcription with the appropriate spacing (Figure 5A). In addition, a sequence resembling the PhoP box consensus motif (T/G)GTTTA-NNNNN-(T/G)GTTTA (where $\mathrm{N}$ is any nucleotide), was found at position $-75 /-59$ relative to the transcriptional start site. Another putative half box, less similar to the expected consensus, was located at $-53 /-48$. The role of this region in driving the transcription of sseK1 was tested using two different promoter probe plasmids: pIC552 and pSB377. A DNA fragment containing the promoter and $5^{\prime}$ untranslated regions of $s s e K 1$, from -500 to +40 , was cloned into these plasmids to generate a lacZ transcriptional fusion (Figure 5B) and a bioluminescent $l u x$ transcriptional fusion (Figure 5C), respectively. Expression of the fusions in wt and phoP backgrounds indicated that the cloned region contained the signals necessary for expression and PhoP-mediated regulation of sseK1. To test the relevance of the putative PhoP binding sites, three independent mutants were obtained in the lux fusion plasmid. Each mutant was constructed by exchanging the conserved TT motif in the middle of a putative half PhoP box sequence for CC (Figure 5A). Whereas mutations at positions $-51 /-50$ had no effect on the expression of the fusion, alteration of the $-62 /-61$ or the $-73 /-72$ motifs completely

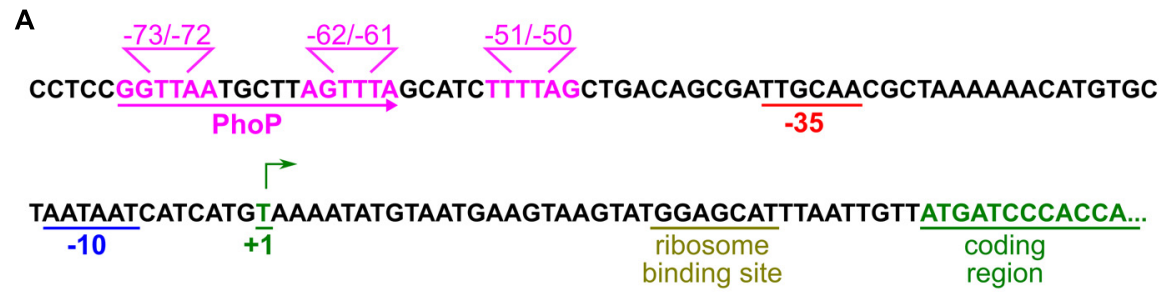

B
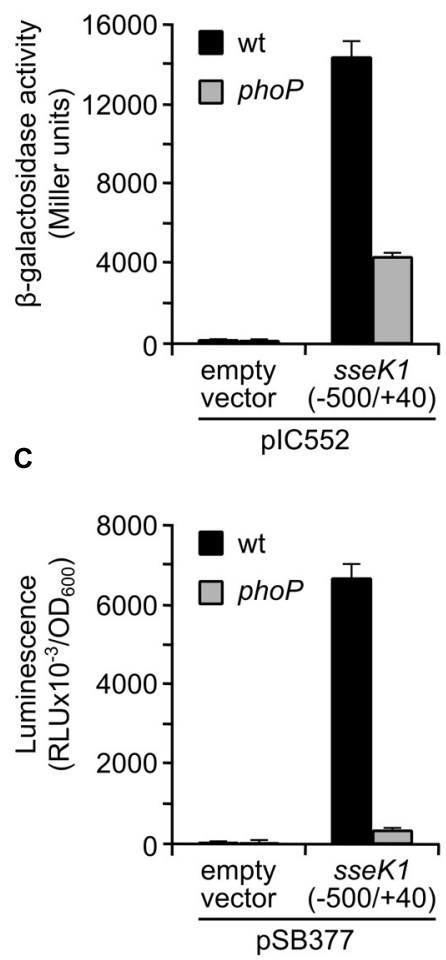

D
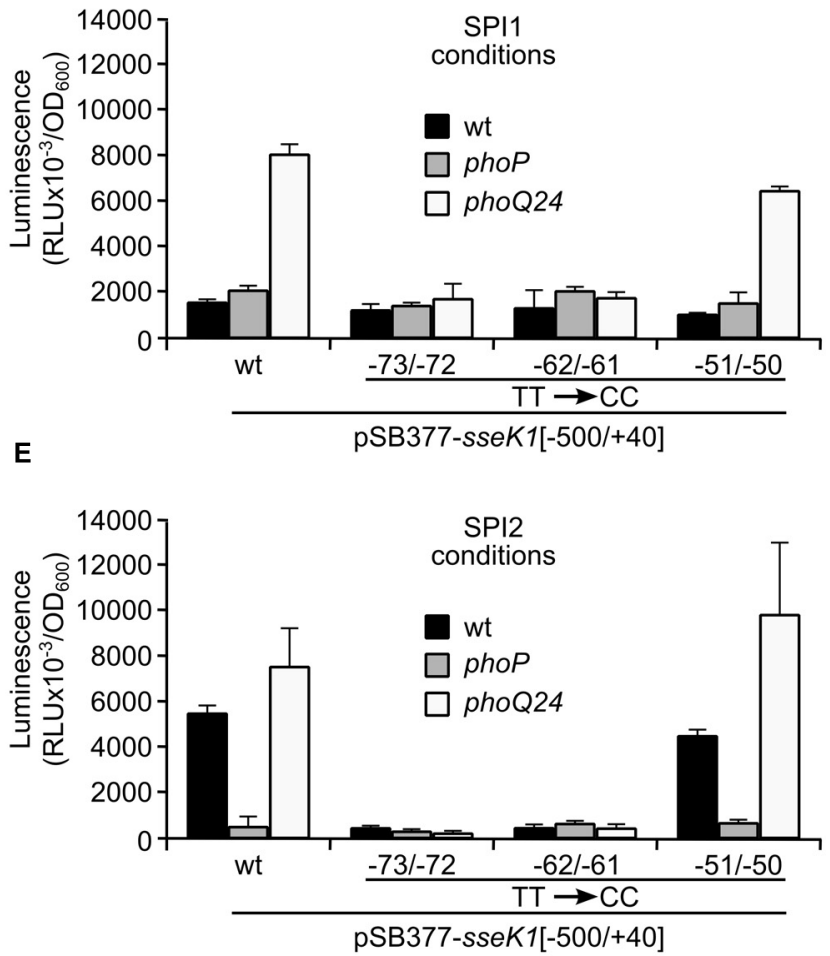

FIGURE 5 | Identification of a PhoP box in the promoter of sseK1.

(A) Analysis of the promoter region of sseK1. The sequence surrounding the transcriptional start site $(+1)$ is shown. The start of the coding sequence, the putative ribosomal binding site and the consensus sequences for $\sigma^{70}$-dependent transcription $(-10$ and -35$)$ are indicated. Putative PhoP-binding motifs are marked in pink and a putative PhoP-box is underlined with an arrow. A fragment of DNA containing the promoter region and $5^{\prime}$ untranslated region of $\operatorname{sse} K 1(-500 /+40)$ was inserted into plasmid plC552 to generate a lacZ transcriptional fusion (B) and into plasmid
pSB377 to generate a luxCDABE transcriptional fusion (C). These plasmids and the corresponding original empty vectors were introduced into $S$. enterica serovar Typhimurium strain 14028 (wt) or a phoP-null mutant, and $\beta$-galactosidase activities or luminescence, respectively, were measured in cultures grown to stationary phase in liquid LPM at $\mathrm{pH}$ 5.8. Luminescence was also measured from the wt, phoP and phoQ24 strains carrying derivatives of pSB377 with the promoter region of sseK1 or variants with the indicated mutations and grown under SPI1 (D) or SPI2 (E) inducing conditions. RLU: relative light units. 
abrogated PhoP regulation of the fusion under SPI1 (Figure 5D) and SPI2-inducing conditions (Figure 5E). These results suggest that the region $-75 /-59$ constitutes a complete PhoP binding box.

Finally, an electrophoretic mobility shift assay was used to analyze the binding of PhoP to the promoter of sseK1. The promoters of $\operatorname{sly} B$ and $p h o N$ were used as positive and negative controls, respectively. Phosphorylated $\mathrm{His}_{6}$-PhoP and PCRamplified DNA fragment containing the relevant promoters were used in these experiments. As seen in Figure 6A, PhoP was able to bind to the $s l y B$ and sseK 1 promoters and no binding was observed to the $p h o N$ promoter. In addition, mutations at positions $-61 /-62$ and $-72 /-73$, prevented PhoP binding (Figure 6B). These results provide additional support to the hypothesis that the region $-75 /-59$ is a PhoP binding box.

\section{Expression of sseK1 Inside Macrophages}

We took advantage of the sseK1::lux transcriptional fusion described above to study expression of sseK 1 during infection of RAW264.7 macrophages. Salmonella strains expressing this fusion were used to infect cultures of these cells in 96-well plates. As seen in Figure 7, luminescence per wild-type CFU was increased 4 and $8 \mathrm{~h}$ p.i. compared to $2 \mathrm{~h}$ p.i., suggesting that

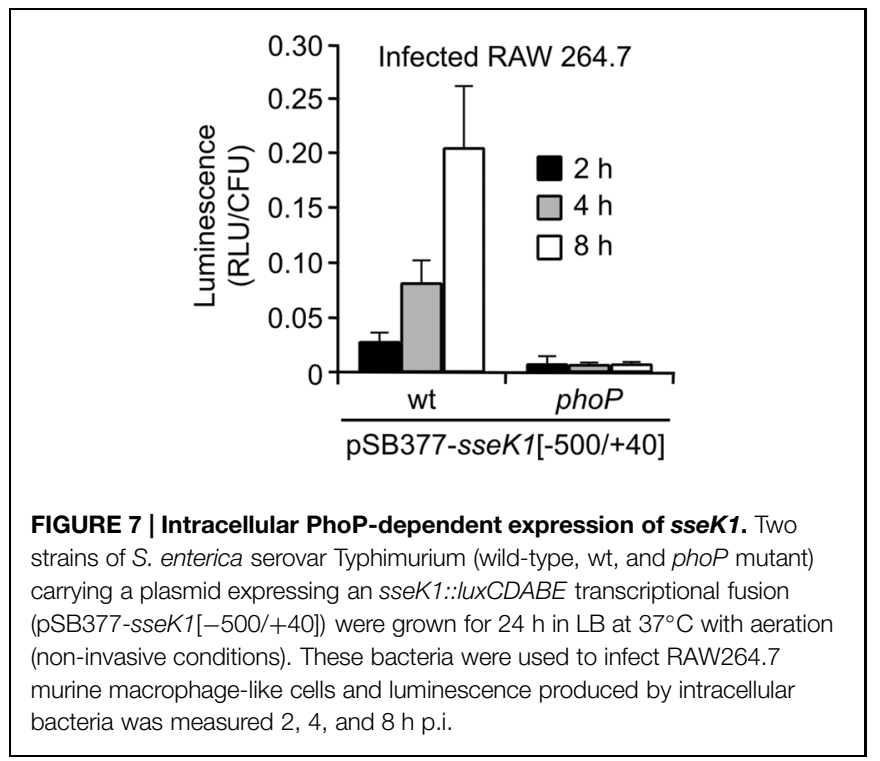

sseK 1 expression is induced, together with T3SS2, in response to intravacuolar signals. In contrast, intracellular induction was not observed in a phoP null mutant, giving additional support to the

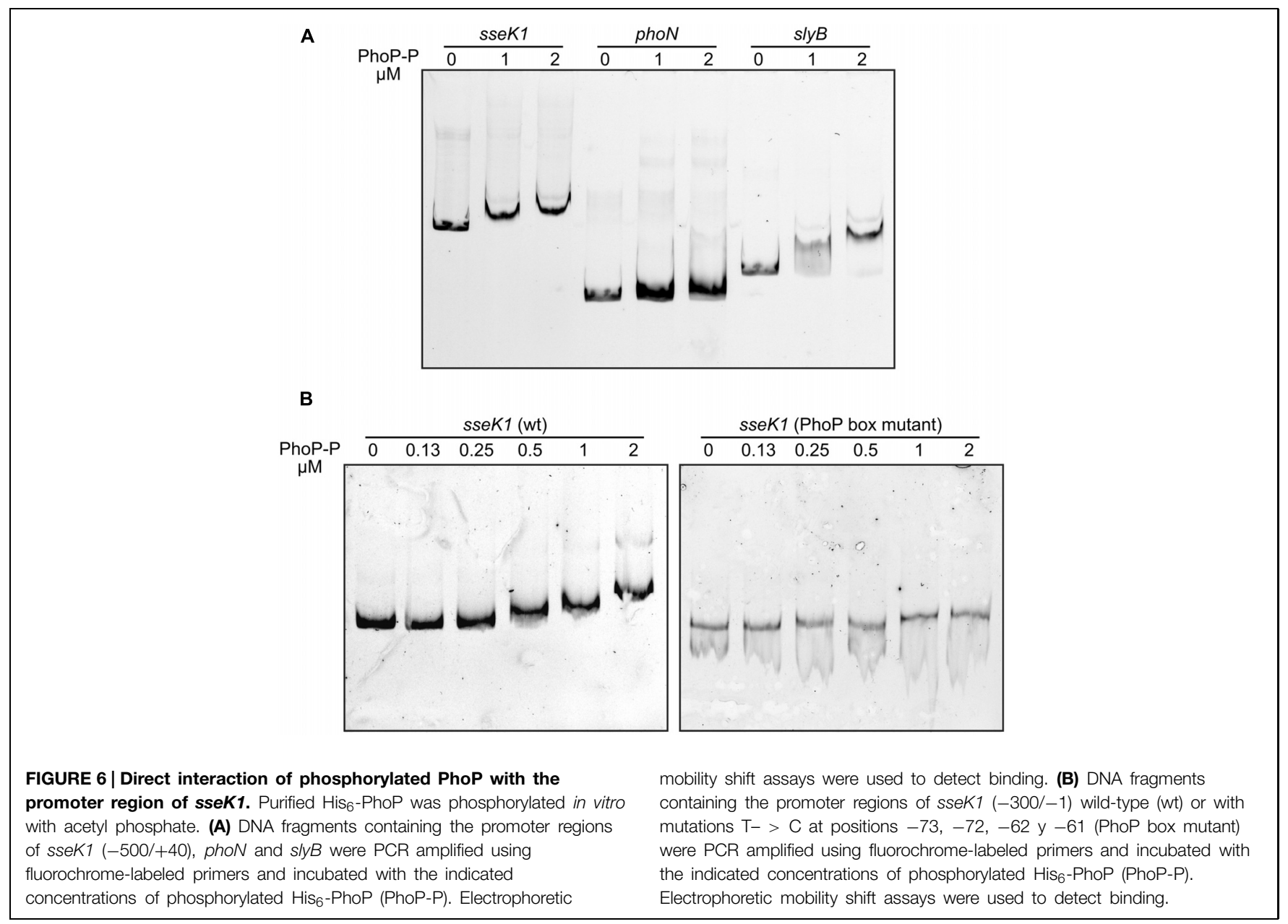


conclusion that $\mathrm{PhoP}$ is a positive regulator of the expression of sseK1.

\section{Discussion}

Although the functions of the members of the SseK family of T3SS effectors are unknown, their amino acid sequence similarities suggested some redundancy in their functions. In previous studies, virulence attenuation was only shown for the triple sseK1 sseK2 sseK3 or the double sseK1 sseK2 mutants. The results presented here, however, clearly show that SseK1 is important in itself during the systemic phase of the infection in the mouse model, since a single sseK1 mutant is significantly attenuated after oral and intraperitoneal infections (Figure 1). In addition, our efforts to detect secretion of SseK2 and SseK3 were unsuccessful, probably due to the low expression levels of these proteins under the conditions tested (data not shown). Our results also suggest that SseK1 is not necessary for invasion or intracellular proliferation in seven different mammalian cell lines. This is in agreement with previous attempts that were unable to find a phenotype following infection of HeLa, Caco2 or RAW264.7 cells (Kujat Choy et al., 2004; Brown et al., 2011; Buckner et al., 2011). However, one of these reports showed a $60 \%$ reduction in the replication index of the triple mutant sseK1 sseK2 sseK3 inside RAW264.7 macrophages (Buckner et al., 2011). The discrepancy between results obtained in different laboratories may be a consequence of differences in experimental details including specific Salmonella strains used and multiplicity of infection.

SseK1 was initially described as a T3SS2 effector in HeLa cells (Kujat Choy et al., 2004; Brown et al., 2011). Here, we carried out a detailed analysis of translocation of this effector using three host cell lines, from three different mammalian species, and two different CyaA' fusions (Figure 3). Our results suggest several conclusions and comments: (i) A first general conclusion is that SseK1 can be secreted through T3SS1 and T3SS2, although with different kinetics depending on the host cell type. Hence, the examination of as many host cell types as possible is essential to fully understand the function of T3SS effectors. (ii) Translocation at short time p.i. $(1-2 \mathrm{~h})$ was T3SS1-dependent but was only observed when the SseK1-CyaA' fusion was expressed from a constitutive promoter in a plasmid. This result suggests that under physiological conditions (expression from its own promoter in the chromosome) SseK1 is not synthetized at sufficient level to allow detectable translocation before invasion of the host cell. It also indicates that the use of chromosomal fusions is more reliable in order to get conclusions about the conditions necessary for translocation of T3SS effectors. (iii) Translocation into epithelial HeLa cells was dependent on T3SS1, since it was not detected in a mutant lacking this system (Figure 3B). This result may be partially explained by the fact that the trigger mechanism mediated by T3SS1 is necessary for the invasion of these cells. As a consequence, translocation from internalized bacteria through T3SS2, if it existed, would not be detected using the $\Delta$ SPI1 mutant. (iv) Translocation into NRK fibroblasts, although T3SS1-dependent at $4 \mathrm{~h}$ p.i., appears to occur through both systems at 8 and $16 \mathrm{~h}$ p.i., since simultaneous inactivation of T3SS1 and T3SS2 is necessary to abolish the increase in cAMP (Figure 3F). Detection of T3SS2-dependent translocation using the T3SS1 mutant is possible in this model because invasion of fibroblasts can take place using a multiplicity of entry mechanisms (Aiastui et al., 2010). (v) Translocation of SseK1 into macrophages infected with noninvasive bacteria was T3SS2-dependent and was detected 8 and $16 \mathrm{~h}$ p.i., but not $4 \mathrm{~h}$ p.i. (Figure 3D). This is similar to the timing observed for T3SS2-dependent SseK1 translocation into fibroblasts infected with invasive bacteria and suggests that this system begins to be functional between 4 and $8 \mathrm{~h}$ after internalization in both cell types. The results obtained in RAW cells also suggest that non-invasive phagocytized bacteria are unable to induce T3SS1 inside these cells.

These results fit well into the context of a previous report showing simultaneous expression of T3SS1 and T3SS2 inside HeLa cells (Hautefort et al., 2008). This initially surprising coexpression was explained by the existence of two subpopulations of Salmonella in epithelial cells: a T3SS2-induced intravacuolar subpopulation and a T3SS1-induced cytosolic subpopulation (Knodler et al., 2010). Cytosolic Salmonella are also detected in fibroblasts and macrophages, although the permissiveness for Salmonella survival and replication in the cytosol is dependent upon the cell type (reviewed in Knodler, 2015).

In this study, we also used a combination of lac, 3xFLAG and $l u x$ fusions to analyze the environmental conditions and the genetic factors involved in the regulation of the expression of sseK1. Maximal expression in rich medium was obtained with $0.3 \mathrm{M} \mathrm{NaCl}$ and modest repression was observed with lower and higher salt concentrations (Figure 2B). Two additional factors that decreased expression of sseK1 in rich medium were low $\mathrm{pH}$ and butyric acid (Figure 2C), a major short chain fatty acid produced in the intestine by anaerobic bacterial fermentation. This organic acid is known to repress SPI1 and other T3SS1-related genes (Lawhon et al., 2002; Gantois et al., 2006; Gong et al., 2009; Cardenal-Muñoz and RamosMorales, 2011). Expression in a minimal medium mimicking intravacuolar conditions (LPM) was higher than in rich medium (Figure 2A). However, acidic $\mathrm{pH}$, which is one of the environmental cues used to induce SPI2, had a negative impact on the expression of sseK1 also in minimal medium (Figure 2D). These data, together with translocation data shown in Figure 3 and discussed above, suggest that expression of sseK1 could be partially repressed during passage through the stomach and the gut, but it would be induced after invasion of host cells and specially after release into the cytosol of non-phagocytic cells.

Among the SPI1 and SPI2 regulators that we tested, only the PhoQ/PhoP two-component regulatory system had a significant effect on the expression of sseK1 (Figure 4). PhoQ is a membrane protein that activates $\mathrm{PhoP}$ in response to low $\mathrm{Mg}^{++}$concentration (García Véscovi et al., 1996; Montagne et al., 2001). PhoP is a transcription factor that regulates expression of about $3 \%$ of the Salmonella genes (Miller and Mekalanos, 1990). These genes are involved in the control of physiological and virulence functions. Positive regulation of $s s e K 1$ by this system is consistent with the effect of $\mathrm{Mg}^{++}$concentrations on its expression (Figure 2D). 
The results obtained at the protein level with an SseK1$3 \times$ FLAG fusion are consistent with a previous report using a 2xHA fusion (Kujat Choy et al., 2004) and indicated that SseK1 was undetectable in a phoP null background. Our results also showed that this dramatic effect is observed specifically under SPI2-inducing conditions (Figure 4C), suggesting that under SPI1-inducing conditions there are other unidentified factors allowing synthesis of SseK1 in the absence of PhoP. The comparison between the results obtained at the protein level (Western blot in Figures 4C,D) and the results obtained using a chromosomal sseK1::lacZ translational fusion ( $\beta$-galactosidase activities in Figure 4B) also suggests an indirect posttranslational effect in addition to the transcriptional effect that is expected for a regulator like PhoP.

Whereas $\mathrm{PhoQ} / \mathrm{PhoP}$ is considered an ancestral regulatory system that is conserved in enteric bacteria and senses $\mathrm{Mg}^{++}$concentrations, the two-component system SsrA/SsrB is Salmonella-specific and is activated by acidic $\mathrm{pH}$ (Miao et al., 2002; Mulder et al., 2015). SsrB is necessary for the expression of T3SS2 and some of its effectors that are encoded outside SPI2 (Ochman et al., 1996; Cirillo et al., 1998; Hensel et al., 1998; Worley et al., 2000). Since PhoP controls expression of the response regulator SsrB at the transcriptional level and of the sensor SsrA at a posttranscriptional level (Bijlsma and Groisman, 2005), it also indirectly regulates expression of SsrB-regulated genes. However, our epistasis analysis combining an $s s r B$ null mutation with a phoQ24 activating mutation (Figure 4) clearly showed that the effect of PhoP on sseK1 was SsrB-independent, which is consistent with the induction of sseK1 expression by low $\mathrm{Mg}^{++}$concentrations but not by low $\mathrm{pH}$. This result also suggested the possibility of direct regulation of sseK1 by PhoP. Two lines of evidence support this hypothesis: (i) PhoP regulation of a lux transcriptional fusion was abrogated by mutations in a putative PhoP-box that was detected in the promoter region of

\section{References}

Aiastui, A., Pucciarelli, M. G., and García-Del Portillo, F. (2010). Salmonella enterica serovar typhimurium invades fibroblasts by multiple routes differing from the entry into epithelial cells. Infect. Immun. 78, 2700-2713. doi: 10.1128/IAI.01389-09

Baisón-Olmo, F., Cardenal-Muñoz, E., and Ramos-Morales, F. (2012). PipB2 is a substrate of the Salmonella pathogenicity island 1-encoded type III secretion system. Biochem. Biophys. Res. Commun. 423, 240-246. doi: 10.1016/j.bbrc.2012.05.095

Bajaj, V., Hwang, C., and Lee, C. A. (1995). hilA is a novel ompR/toxR family member that activates the expression of Salmonella typhimurium invasion genes. Mol. Microbiol. 18, 715-727. doi: 10.1111/j.1365-2958.1995.mmi_180 40715.x

Bajaj, V., Lucas, R. L., Hwang, C., and Lee, C. A. (1996). Co-ordinate regulation of Salmonella typhimurium invasion genes by environmental and regulatory factors is mediated by control of hilA expression. Mol. Microbiol. 22, 703-714. doi: 10.1046/j.1365-2958.1996.d01-1718.x

Bakowski, M. A., Braun, V., and Brumell, J. H. (2008). Salmonella-containing vacuoles: directing traffic and nesting to grow. Traffic 9, 2022-2031. doi: 10.1111/j.1600-0854.2008.00827.x

Bijlsma, J. J., and Groisman, E. A. (2005). The PhoP/PhoQ system controls the intramacrophage type three secretion system of Salmonella enterica. Mol. Microbiol. 57, 85-96. doi: 10.1111/j.1365-2958.2005.04668.x
sseK1 (Figure 5). (ii) Binding of PhoP to the promoter region of sseK1 was confirmed by EMSA analysis (Figure 6A). In addition, mutation of the putative PhoP-box significantly reduced binding (Figure 6B).

The bioluminescent fusion used here showed great sensitivity and was used to demonstrate in vivo PhoP-dependent induction of sseK1 inside macrophages (Figure 7), giving stronger support to the conclusions obtained using a culture medium (LPM) that imitates intravacuolar conditions (Figure 4). This fusion could also be, in principle, useful for future experiments regarding the study of expression of sseK 1 inside animal models.

In summary, our results suggest that the T3SS effector SseK1 is a virulent factor that responds to a complex array of environmental signals. Expression of sseK1 is directly activated by PhoP under SPI2-inducing conditions and, probably, by other unknown regulators under SPI1-inducing conditions. In response to these signals and regulators SseK1 is expressed and translocated through both T3SS1 and T3SS2 when Salmonella is inside the host cell. Additional experiments will be necessary to understand the specific role of SseK1 during infections.

\section{Acknowledgments}

This work was supported by grants SAF2010-15015 and SAF2013-46229-R, from the Spanish Ministry of Economy and Competitiveness and the European Regional Development Fund. FBO is a recipient of a FPI fellowship from the Spanish Ministry of Economy and Competitiveness. We are grateful to Anja Wiechmann and Paul Williams for the gift of plasmid pSB377 and to Javier López-Garrido for the construction of strains SV5373 and SV6402. We also thank Modesto Carballo, Laura Navarro and Cristina Reyes of the Servicio de Biología (CITIUS, Universidad de Sevilla) for help in experiments performed at the facility.

Boyle, E. C., Brown, N. F., and Finlay, B. B. (2006). Salmonella enterica serovar Typhimurium effectors SopB, SopE, SopE2 and SipA disrupt tight junction structure and function. Cell Microbiol. 8, 1946-1957. doi: 10.1111/j.14625822.2006.00762.x

Brown, N. F., Coombes, B. K., Bishop, J. L., Wickham, M. E., Lowden, M. J., Gal-Mor, O., et al. (2011). Salmonella phage ST64B encodes a member of the SseK/NleB effector family. PLoS ONE 6:e17824. doi: 10.1371/journal.pone.0017824

Brumell, J. H., Kujat-Choy, S., Brown, N. F., Vallance, B. A., Knodler, L. A., and Finlay, B. B. (2003). SopD2 is a novel type III secreted effector of Salmonella typhimurium that targets late endocytic compartments upon delivery into host cells. Traffic 4, 36-48. doi: 10.1034/j.1600-0854.2003. 40106.x

Buckner, M. M., Croxen, M. A., Arena, E. T., and Finlay, B. B. (2011). A comprehensive study of the contribution of Salmonella enterica serovar Typhimurium SPI2 effectors to bacterial colonization, survival, and replication in typhoid fever, macrophage, and epithelial cell infection models. Virulence 2, 208-216. doi: 10.4161/viru.2.3.15894

Bullock, W. O., Fernandez, J. M., and Short, J. M. (1987). XL1-BLUE: a high efficiency plasmid transforming RecA Escherichia coli strain with betagalactosidase selection. BioTechniques 5, 376-379.

Cardenal-Muñoz, E., and Ramos-Morales, F. (2011). Analysis of the expression, secretion and translocation of the Salmonella enterica type III secretion system effector SteA. PLoS ONE 6:e26930. doi: 10.1371/journal.pone.0026930 
Cardenal-Muñoz, E., and Ramos-Morales, F. (2013). DsbA and MgrB regulate steA expression through the two-component system $\mathrm{PhoQ} / \mathrm{PhoP}$ in Salmonella enterica. J. Bacteriol. 195, 2368-2378. doi: 10.1128/JB.00110-13

Chan, R. K., Botstein, D., Watanabe, T., and Ogata, Y. (1972). Specialized transduction of tetracycline resistance by phage P22 in Salmonella typhimurium. II. Properties of a high-frequency-transducing lysate. Virology 50, 883-898. doi: 10.1016/0042-6822(72)90442-4

Chen, Z., and Jiang, X. (2014). Microbiological safety of chicken litter or chicken litter-based organic fertilizers: a review. Agriculture 4, 1-29. doi: 10.3390/agriculture4010001

Cherepanov, P. P., and Wackernagel, W. (1995). Gene disruption in Escherichia coli: TcR and KmR cassettes with the option of Flp-catalyzed excision of the antibiotic-resistance determinant. Gene 158, 9-14. doi: 10.1016/03781119(95)00193-A

Cirillo, D. M., Valdivia, R. H., Monack, D. M., and Falkow, S. (1998). Macrophagedependent induction of the Salmonella pathogenicity island 2 type III secretion system and its role in intracellular survival. Mol. Microbiol. 30, 175-188. doi: 10.1046/j.1365-2958.1998.01048.x

Cordero-Alba, M., and Ramos-Morales, F. (2014). Patterns of expression and translocation of the ubiquitin ligase SlrP in Salmonella enterica serovar Typhimurium. J. Bacteriol. 196, 3912-3922. doi: 10.1128/JB.02158-14

Datsenko, K. A., and Wanner, B. L. (2000). One-step inactivation of chromosomal genes in Escherichia coli K-12 using PCR products. Proc. Natl. Acad. Sci. U.S.A. 97, 6640-6645. doi: 10.1073/pnas.120163297

Ellermeier, C. D., Janakiraman, A., and Slauch, J. M. (2002). Construction of targeted single copy lac fusions using lambda Red and FLP-mediated sitespecific recombination in bacteria. Gene 290, 153-161. doi: 10.1016/S03781119(02)00551-6

Fink, S. L., and Cookson, B. T. (2007). Pyroptosis and host cell death responses during Salmonella infection. Cell Microbiol 9, 2562-2570. doi: 10.1111/j.14625822.2007.01036.x

Galán, J. E., and Curtiss, R. III. (1989). Cloning and molecular characterization of genes whose products allow Salmonella typhimurium to penetrate tissue culture cells. Proc. Natl. Acad. Sci. U.S.A. 86, 6383-6387. doi: 10.1073/pnas.86.1 6.6383

Gal-Mor, O., Elhadad, D., Deng, W., Rahav, G., and Finlay, B. B. (2011). The Salmonella enterica PhoP directly activates the horizontally acquired SPI-2 gene sseL and is functionally different from a $S$. bongori ortholog. PLoS ONE 6:e20024. doi: 10.1371/journal.pone.0020024

Gantois, I., Ducatelle, R., Pasmans, F., Haesebrouck, F., Hautefort, I., Thompson, A., et al. (2006). Butyrate specifically down-regulates Salmonella pathogenicity island 1 gene expression. Appl. Environ. Microbiol. 72, 946-949. doi: 10.1128/AEM.72.1.946-949.2006

García-Calderón, C. B., Casadesús, J., and Ramos-Morales, F. (2007). Rcs and PhoPQ regulatory overlap in the control of Salmonella enterica virulence. J. Bacteriol. 189, 6635-6644. doi: 10.1128/JB.00640-07

García-Calderón, C. B., García-Quintanilla, M., Casadesús, J., and RamosMorales, F. (2005). Virulence attenuation in Salmonella enterica rcsC mutants with constitutive activation of the Rcs system. Microbiology 151, 579-588. doi: 10.1099/mic.0.27520-0

García Véscovi, E., Soncini, F. C., and Groisman, E. A. (1996). Mg2+ as an extracellular signal: environmental regulation of Salmonella virulence. Cell 84, 165-174. doi: 10.1016/S0092-8674(00)81003-X

Gong, H., Su, J., Bai, Y., Miao, L., Kim, K., Yang, Y., et al. (2009). Characterization of the expression of Salmonella Type III secretion system factor PrgI, SipA, SipB, SopE2, SpaO, and SptP in cultures and in mice. BMC Microbiol. 9:73. doi: 10.1186/1471-2180-9-73

Groisman, E. A., Chiao, E., Lipps, C. J., and Heffron, F. (1989). Salmonella typhimurium phoP virulence gene is a transcriptional regulator. Proc. Natl. Acad. Sci. U.S.A. 86, 7077-7081. doi: 10.1073/pnas.86.18.7077

Guiney, D. G., and Lesnick, M. (2005). Targeting of the actin cytoskeleton during infection by Salmonella strains. Clin. Immunol. 114, 248-255. doi: 10.1016/j.clim.2004.07.014

Gyles, C., and Boerlin, P. (2014). Horizontally transferred genetic elements and their role in pathogenesis of bacterial disease. Vet. Pathol. 51, 328-340. doi: $10.1177 / 0300985813511131$

Habyarimana, F., Sabag-Daigle, A., and Ahmer, B. M. (2014). The SdiA-regulated gene srgE encodes a type III secreted effector. J. Bacteriol. 196, 2301-2312. doi: 10.1128/JB.01602-14
Hanahan, D. (1983). Studies on transformation of Escherichia coli with plasmids. J. Mol. Biol. 166, 557-580. doi: 10.1016/S0022-2836(83)80284-8

Haneda, T., Ishii, Y., Shimizu, H., Ohshima, K., Iida, N., Danbara, H., et al. (2012). Salmonella type III effector SpvC, a phosphothreonine lyase, contributes to reduction in inflammatory response during intestinal phase of infection. Cell. Microbiol. 14, 485-499. doi: 10.1111/j.1462-5822.2011.01733.x

Hautefort, I., Thompson, A., Eriksson-Ygberg, S., Parker, M. L., Lucchini, S., Danino, V., et al. (2008). During infection of epithelial cells Salmonella enterica serovar typhimurium undergoes a time-dependent transcriptional adaptation that results in simultaneous expression of three type 3 secretion systems. Cell. Microbiol. 10, 958-984. doi: 10.1111/j.1462-5822.2007.01099.x

Hensel, M., Shea, J. E., Waterman, S. R., Mundy, R., Nikolaus, T., Banks, G., et al. (1998). Genes encoding putative effector proteins of the type III secretion system of Salmonella pathogenicity island 2 are required for bacterial virulence and proliferation in macrophages. Mol. Microbiol. 30, 163-174. doi: 10.1046/j.1365-2958.1998.01047.x

Jones, M. A., Wood, M. W., Mullan, P. B., Watson, P. R., Wallis, T. S., and Galyov, E. E. (1998). Secreted effector proteins of Salmonella dublin act in concert to induce enteritis. Infect. Immun. 66, 5799-57804.

Knodler, L. A. (2015). Salmonella enterica: living a double life in epithelial cells. Curr. Opin. Microbiol. 23C, 23-31. doi: 10.1016/j.mib.2014.10.010

Knodler, L. A., Vallance, B. A., Celli, J., Winfree, S., Hansen, B., Montero, M., et al. (2010). Dissemination of invasive Salmonella via bacterial-induced extrusion of mucosal epithelia. Proc. Natl. Acad. Sci. U.S.A. 107, 17733-17738. doi: 10.1073/pnas.1006098107

Kroger, C., Dillon, S. C., Cameron, A. D., Papenfort, K., Sivasankaran, S. K., Hokamp, K., et al. (2012). The transcriptional landscape and small RNAs of Salmonella enterica serovar Typhimurium. Proc. Natl. Acad. Sci. U.S.A. 109, E1277-E1286. doi: 10.1073/pnas.1201061109

Kujat Choy, S. L., Boyle, E. C., Gal-Mor, O., Goode, D. L., Valdez, Y., Vallance, B. A., et al. (2004). SseK1 and SseK2 are novel translocated proteins of Salmonella enterica serovar typhimurium. Infect. Immun. 72, 5115-5125. doi: 10.1128/IAI.72.9.5115-5125.2004

Lawhon, S. D., Maurer, R., Suyemoto, M., and Altier, C. (2002). Intestinal short-chain fatty acids alter Salmonella typhimurium invasion gene expression and virulence through BarA/SirA. Mol. Microbiol. 46, 1451-1464. doi: 10.1046/j.1365-2958.2002.03268.x

Liao, A. P., Petrof, E. O., Kuppireddi, S., Zhao, Y., Xia, Y., Claud, E. C., et al. (2008). Salmonella type III effector AvrA stabilizes cell tight junctions to inhibit inflammation in intestinal epithelial cells. PLOS ONE 3:e2369. doi: 10.1371/journal.pone.0002369

Lin, D., Rao, C. V., and Slauch, J. M. (2008). The Salmonella SPI1 type three secretion system responds to periplasmic disulfide bond status via the flagellar apparatus and the RcsCDB system. J. Bacteriol. 190, 87-97. doi: 10.1128/JB.01 323-07

López-Garrido, J., and Casadesús, J. (2010). Regulation of Salmonella enterica pathogenicity island 1 by DNA adenine methylation. Genetics 184, 637-649. doi: 10.1534/genetics.109.108985

Macián, F., Pérez-Roger, I., and Armengod, M. E. (1994). An improved vector system for constructing transcriptional lacZ fusions: analysis of regulation of the dnaA, dnaN, recF and gyrB genes of Escherichia coli. Gene 145, 17-24. doi: 10.1016/0378-1119(94)90317-4

Maloy, S. R. (1990). Experimental Techniques in Bacterial Genetics. Boston, MA: Jones \& Barlett.

Mazurkiewicz, P., Thomas, J., Thompson, J. A., Liu, M., Arbibe, L., Sansonetti, P., et al. (2008). SpvC is a Salmonella effector with phosphothreonine lyase activity on host mitogen-activated protein kinases. Mol. Microbiol. 67, 1371-1383. doi: 10.1111/j.1365-2958.2008.06134.x

Miao, E. A., Freeman, J. A., and Miller, S. I. (2002). Transcription of the SsrAB regulon is repressed by alkaline $\mathrm{pH}$ and is independent of PhoPQ and magnesium concentration. J. Bacteriol. 184, 1493-1497. doi: 10.1128/JB.184.5.14931497.2002

Miao, E. A., and Miller, S. I. (2000). A conserved amino acid sequence directing intracellular type III secretion by Salmonella typhimurium. Proc. Natl. Acad. Sci. U.S.A. 97, 7539-7544. doi: 10.1073/pnas.97.13.7539

Miao, E. A., Scherer, C. A., Tsolis, R. M., Kingsley, R. A., Adams, L. G., Baumler, A. J., et al. (1999). Salmonella typhimurium leucine-rich repeat proteins are targeted to the SPI1 and SPI2 type III secretion systems. Mol. Microbiol. 34, 850-864. doi: 10.1046/j.1365-2958.1999.01651.x 
Miller, J. H. (1972). Experiments in Molecular Genetics. Cold Spring Harbor, NY: Cold Spring Harbor Laboratory Press.

Miller, S. I., and Mekalanos, J. J. (1990). Constitutive expression of the phoP regulon attenuates Salmonella virulence and survival within macrophages. J. Bacteriol. 172, 2485-2490.

Montagne, M., Martel, A., and Le Moual, H. (2001). Characterization of the catalytic activities of the PhoQ histidine protein kinase of Salmonella enterica serovar Typhimurium. J. Bacteriol. 183, 1787-1791. doi: 10.1128/JB.183.5.17871791.2001

Mouslim, C., Delgado, M., and Groisman, E. A. (2004). Activation of the $\mathrm{Rcs} C / Y o j N / R c s B$ phosphorelay system attenuates Salmonella virulence. Mol. Microbiol. 54, 386-395. doi: 10.1111/j.1365-2958.2004.04293.x

Mulder, D. T., Mcphee, J. B., Reid-Yu, S. A., Stogios, P. J., Savchenko, A., and Coombes, B. K. (2015). Multiple histidines in the periplasmic domain of the Salmonella enterica sensor kinase SsrA enhance signaling in response to extracellular acidification. Mol. Microbiol. 95, 678-691. doi: 10.1111/mmi.12895

Niemann, G. S., Brown, R. N., Gustin, J. K., Stufkens, A., Shaikh-Kidwai, A. S., $\mathrm{Li}$, J., et al. (2011). Discovery of novel secreted virulence factors from Salmonella enterica serovar Typhimurium by proteomic analysis of culture supernatants. Infect. Immun. 79, 33-43. doi: 10.1128/IAI.00771-10

Ochman, H., Soncini, F. C., Solomon, F., and Groisman, E. A. (1996). Identification of a pathogenicity island required for Salmonella survival in host cells. Proc. Natl. Acad. Sci. U.S.A. 93, 7800-7804. doi: 10.1073/pnas.93.15.7800

Prieto, A. I., Ramos-Morales, F., and Casadesús, J. (2004). Bile-induced DNA damage in Salmonella enterica. Genetics 168, 1787-1794. doi: 10.1534/genetics. 104.031062

Ramos-Morales, F. (2012). Impact of Salmonella enterica type III secretion system effectors on the eukaryotic host cell. ISRN Cell Biol. 2012:787934. doi: $10.5402 / 2012 / 787934$

Ramos-Morales, F., Cardenal-Muñoz, E., Cordero-Alba, M., and Baisón-Olmo, F. (2015). Generation and use of site-directed chromosomal cyaA' translational fusions in Salmonella enterica. Methods Mol. Biol. 1225, 93-104. doi: 10.1007/978-1-4939-1625-2_6

Schechter, L. M., and Lee, C. A. (2001). AraC/XylS family members, HilC and HilD, directly bind and derepress the Salmonella typhimurium hilA promoter. Mol. Microbiol. 40, 1289-1299. doi: 10.1046/j.1365-2958.2001.02462.x

Schmieger, H. (1972). Phage P22-mutants with increased or decreased transduction abilities. Mol. Gen. Genet. 119, 75-88. doi: 10.1007/BF00270447

Schroeder, N., Mota, L. J., and Meresse, S. (2011). Salmonella-induced tubular networks. Trends Microbiol. 19, 268-277. doi: 10.1016/j.tim.2011.01.006

Segura, I., Casadesús, J., and Ramos-Morales, F. (2004). Use of mixed infections to study cell invasion and intracellular proliferation of Salmonella enterica in eukaryotic cell cultures. J. Microbiol. Methods 56, 83-91. doi: 10.1016/j.mimet.2003.09.004
Shea, J. E., Hensel, M., Gleeson, C., and Holden, D. W. (1996). Identification of a virulence locus encoding a second type III secretion system in Salmonella typhimurium. Proc. Natl. Acad. Sci. U.S.A. 93, 2593-2597. doi: 10.1073/pnas.93.6.2593

Steele-Mortimer, O. (2008). The Salmonella-containing vacuole: moving with the times. Curr. Opin. Microbiol. 11, 38-45. doi: 10.1016/j.mib.2008. 01.002

Tang, Y. T., Gao, R., Havranek, J. J., Groisman, E. A., Stock, A. M., and Marshall, G. R. (2012). Inhibition of bacterial virulence: drug-like molecules targeting the Salmonella enterica PhoP response regulator. Chem. Biol. Drug Des. 79, 1007-1017. doi: 10.1111/j.1747-0285.2012.01362.x

Tsolis, R. M., Kingsley, R. A., Townsend, S. M., Ficht, T. A., Adams, L. G., and Baumler, A. J. (1999). Of mice, calves, and men. Comparison of the mouse typhoid model with other Salmonella infections. Adv. Exp. Med. Biol. 473, 261-274. doi: 10.1007/978-1-4615-4143-1_28

Uzzau, S., Brown, D. J., Wallis, T., Rubino, S., Leori, G., Bernard, S., et al. (2000). Host adapted serotypes of Salmonella enterica. Epidemiol. Infect. 125, 229-255. doi: 10.1017/S0950268899004379

Uzzau, S., Figueroa-Bossi, N., Rubino, S., and Bossi, L. (2001). Epitope tagging of chromosomal genes in Salmonella. Proc. Natl. Acad. Sci. U.S.A. 98, 15264-15269. doi: 10.1073/pnas.261348198

Winson, M. K., Swift, S., Hill, P. J., Sims, C. M., Griesmayr, G., Bycroft, B. W., et al. (1998). Engineering the luxCDABE genes from Photorhabdus luminescens to provide a bioluminescent reporter for constitutive and promoter probe plasmids and mini-Tn5 constructs. FEMS Microbiol. Lett. 163, 193-202. doi: 10.1111/j.1574-6968.1998.tb13045.x

Worley, M. J., Ching, K. H., and Heffron, F. (2000). Salmonella SsrB activates a global regulon of horizontally acquired genes. Mol. Microbiol. 36, 749-761. doi: 10.1046/j.1365-2958.2000.01902.x

Zhang, Y., Higashide, W. M., Mccormick, B. A., Chen, J., and Zhou, D. (2006). The inflammation-associated Salmonella SopA is a HECT-like E3 ubiquitin ligase. Mol. Microbiol. 62, 786-793. doi: 10.1111/j.1365-2958.2006. 05407.x

Conflict of Interest Statement: The authors declare that the research was conducted in the absence of any commercial or financial relationships that could be construed as a potential conflict of interest.

Copyright $\odot 2015$ Baisón-Olmo, Galindo-Moreno and Ramos-Morales. This is an open-access article distributed under the terms of the Creative Commons Attribution License (CC BY). The use, distribution or reproduction in other forums is permitted, provided the original author(s) or licensor are credited and that the original publication in this journal is cited, in accordance with accepted academic practice. No use, distribution or reproduction is permitted which does not comply with these terms. 